\title{
Dimorphic Sessile Apterae of the Aphid Neothoracaphis glaucae (Hemiptera) on the Evergreen Oak Quercus glauca
}

\author{
Shigeyuki Aoki ${ }^{1},{ }^{1}$ Utako Kurosu, ${ }^{2}$ Keigo Uematsu, ${ }^{3}$ Takema Fukatsu, ${ }^{4}$ \\ and Mayako Kutsukake ${ }^{4}$ \\ ${ }^{1}$ Faculty of Economics, Rissho University, Tokyo, Japan \\ ${ }^{2}$ Faculty of Economics, Chuo University, Hachioji, Japan \\ ${ }^{3}$ Department of Evolutionary Studies of Biosystems, SOKENDAI (The Graduate University for Advanced Studies), \\ Hayama, Japan \\ ${ }^{4}$ Bioproduction Research Institute, National Institute of Advanced Industrial Science and Technology (AIST), Tsukuba, Japan \\ Correspondence should be addressed to Shigeyuki Aoki; oregma@rb3.so-net.ne.jp
}

Received 30 July 2019; Accepted 6 September 2019; Published 11 November 2019

Academic Editor: David Roubik

Copyright ( 2019 Shigeyuki Aoki et al. This is an open access article distributed under the Creative Commons Attribution License, which permits unrestricted use, distribution, and reproduction in any medium, provided the original work is properly cited.

\begin{abstract}
Species of the aphid genus Neothoracaphis (Hormaphidinae, Nipponaphidini) produce tiny, sessile, sclerotized apterous adults on leaves of oaks. Among Japanese species, "N. glaucae" has been known to have the largest, ovate apterae, while "N. saramaoensis" has smaller, elongated oval apterae on Quercus glauca. Through examining mitochondrial DNA sequences of Japanese Neothoracaphis species, we found that the two are the same species with a clear dimorphism. Neothoracaphis glaucae (Takahashi) was adopted as the valid name for the species. In Tokyo, Japan, apterae of the smaller type are abundantly seen throughout the year, and those of the larger type are generally few in number from summer to autumn. Alates, which are supposed to be sexuparae, appear from November to January. Nymphs developing into the alates are covered with long, semitransparent, bristle-like wax filaments. We conclude that $N$. querciphaga, N. elongata, and N. yanonis are distinct species and that both the genus Neothoracaphis and the three Neothoracaphis species other than N. yanonis form monophyletic groups among Japanese Nipponaphidini species we have examined.
\end{abstract}

\section{Introduction}

The aphid genus Neothoracaphis belongs to the tribe Nipponaphidini (Hormaphidinae, Aphididae), and about ten nominal species have been reported from East Asia [1-3]. Except for one species, Neothoracaphis yanonis, which migrates between Distylium spp. (the primary host) and deciduous Quercus spp. (the secondary host) [4-7], all the other species have been recorded only from leaves of their secondary hosts, deciduous or evergreen Quercus trees (some from Lithocarpus trees [1]) and therefore have been thought to be anholocyclic $[2,8]$. The apterous adults (apterae) on the secondary hosts are sessile, heavily sclerotized with reduced tarsi and no cornicles, and very small, less than $1 \mathrm{~mm}$ and at times around $0.5 \mathrm{~mm}$ in length $[1,2]$. In Japan, five nominal species have been recorded: N. yanonis on Q. serrata, Q. dentata, and Q. crispula (and also on Distylium racemosum) $[5,8], N$. elongata on Q. myrsinifolia, Q. sessilifolia, and Q. acuta $[8,9]$, N. querciphaga on Q. myrsinifolia [8], N. saramaoensis on Q. glauca [8], and N. glaucae on Q. glauca [8]. Of them, N. glaucae and $N$. saramaoensis are rather commonly found on the undersides of leaves of Q. glauca. Neothoracaphis glaucae produces apterous adults that are the largest among the Japanese species and ovate in shape (Figure 1(a)), while N. saramaoensis produces apterae which are smaller and elongated oval in shape (Figure 1(b)); the two seem to be very different from each other. However, we have often found the two kinds of apterae on the same leaf of Q. glauca. This led us to suspect that the two might be different phenotypes of a single species. The prime issue we address in this paper is whether the two nominal species on Q. glauca are the same species or not. In the course of the present study, we found, in some colonies of the focal species N. glaucae/saramaoensis, bizarre wingpadded nymphs 
(nymphs that develop into alates), which were larger than the apterous adults of $N$. glaucae and covered with many, long, semitransparent, bristle-like wax filaments (Figure 1(c)). Alates of Neothoracaphis have hitherto been unknown from species on evergreen oaks. We wondered whether these nymphs were really of the focal species. In the present paper, we settle the two issues by examining their mitochondrial DNA sequences, describe size dimorphism found in the apterous adults, and discuss the life cycle of the focal species. In addition, by examining mitochondrial DNA sequences of three congeners, $N$. querciphaga, N. elongata, and $N$. yanonis (and some other Nipponaphidini species), we determine whether each nominal species is really a distinct species and whether the Neothoracaphis species constitute a monophyletic group among nipponaphidines.

\section{Materials and Methods}

2.1. Sampling of Apterae of the Focal Species. Apterous generations of the focal species N. glaucae/saramaoensis, as well as those of other species of Neothoracaphis, form sparse colonies on the undersides of leaves of the host oaks [1]. Aphids (apterous adults and nymphs) of the focal species were sampled mainly from a few trees of Quercus glauca in Shinkiba, Tokyo, Japan, in 2013 and 2014. Leaves of some trees were infested with both the larger, glaucae-type ("L-type") apterae (Figures 1(a) and 2(a)) and the smaller, saramaoensis-type ("Stype") apterae (Figures 1(b) and 2(b)). Several infested leaves were cut off the trees and preserved in bottles of $80 \%$ ethanol on 20 January 2014, 28 March 2014, 4 June 2014, 17 September 2013, and 5 November 2014 (Table 1). In and around Tokyo, trees of Q. glauca produce new shoots from April onward. The mean longevity of the leaves is estimated to be two or three years $[10,11]$. New leaves were clearly discriminated from old ones from April to September. Two samples collected in June (\#14117) and September (\#13117) were from old (at least oneyear-old) leaves. These five samples each contained approximately 150-240 apterous adults, which were later slidemounted and used for morphometric analyses (see later sections). We noticed that only S-type apterae were seen on new leaves and, to confirm whether this is the case, sampled a few new leaves of Q. glauca infested with apterae on 22 May 2013, 4 June 2014, 15 July 2013, and 17 September 2013. These four samples from new leaves contained 222 apterous adults in total, and 148 apterae from one of them (\#14115 collected on 4th June) were slide-mounted for morphometry.

Materials for DNA extraction were collected from leaves of Q. glauca in Shinkiba, Ome (Tokyo), and Takao (Tokyo) and from leaves of Q. myrsinifolia in Yugawara (Kanagawa Prefecture) and Kitakyushu (Fukuoka Prefecture), Japan, between 2013 and 2018 (Table 2). Some L-type and S-type apterous adults found in Ome and Takao were separately deposited in vials of $99 \%$ ethanol to determine whether they were of the same species by comparing their mitochondrial DNA sequences.

\subsection{Sampling of Congener Apterae for Comparison.} Apterous adults of three other species of Neothoracaphis were also sampled for morphometry and DNA extraction.
They were $N$. querciphaga, N. elongata, and $N$. yanonis (Figures 2(c), 2(d), and 3). The collection data are presented in Tables 1 and 2. Because there was a considerable amount of variation in the size and shape of apterous adults in $N$. querciphaga, large apterae and small apterae (indicated as "L-type" and "S-type" in Table 2) were collected from a single tree in Ome and Hachioji (Tokyo), and their mitochondrial DNA sequences were examined to confirm that they were of the same species.

\subsection{Sampling of Alate-Generation Aphids of the Focal Species.} Alates of the focal species have hitherto been unknown. We found three alates (Figure $1(\mathrm{~d})$ ) and a number of nymphs that would develop into alates (Figure 1(c)) on the undersides of leaves of Q. glauca in Shinkiba from November to January. We sampled these aphids on 1, 14, and 25 November 2013, 20 January 2014, and 5 and 24 November 2014. Third- and fourth-instar wingpadded nymphs on leaves were kept in plastic containers in the laboratory at room temperature, and a total of 61 alates emerged later. To obtain first-instar nymphs from these alates, 37 alates were confined, together with a piece of paper, in $5 \mathrm{~mL}$ cotton-plugged glass vials to force their larviposition there. Two to eight days later, first-instar nymphs were seen walking in some of the vials, and $80 \%$ ethanol was poured into them. A total of 42 first-instar nymphs were obtained. These nymphs were slidemounted, and their morphology was examined to determine whether the nymphs were sexuals or virginoparae (i.e., whether their mothers were sexuparae or secondary migrants).

The nymphs of the focal species that would develop into alates (Figures1(c), 4(c), and 5(d)) looked very different from nymphs developing into apterae (Figures 4(a) and 4(b)), and we wondered whether they were really of the same species. A few wingpadded nymphs were therefore deposited in vials of 99\% ethanol, and from two of them (\#13154 and \#13187 in Table 2), mitochondrial DNA was extracted and sequenced. Some others, including one first-instar nymph (Figure 4(c)), were kept in $80 \%$ ethanol and later were mounted on glass slides for microscopic examination.

\subsection{Sampling of Alates and Nymphs of Neothoracaphis} yanonis for Comparison. Neothoracaphis yanonis is a very common nipponaphidine in Japan. Galls of the species are seen on almost all trees of Distylium racemosum in Honshu, Shikoku, and Kyushu. Aphids of its secondary-host generation are also commonly found on leaves of Quercus serrata. Neothoracaphis yanonis has been the only species of the genus whose secondary-host generation produces alate sexuparae in Japan [4-6, 8]. To determine whether the firstinstar nymphs produced by alates of the focal species are of the sexual generation or not, it was necessary to compare their morphology with that of first-instar nymphs of N. yanonis. However, there has been no description of firstinstar nymphs of $N$. yanonis in the literature. We therefore sampled, besides adults, first-instar (and later-instar) nymphs of $N$. yanonis that would develop into apterous adults, alate sexuparae, and sexuals from Q. serrata or 


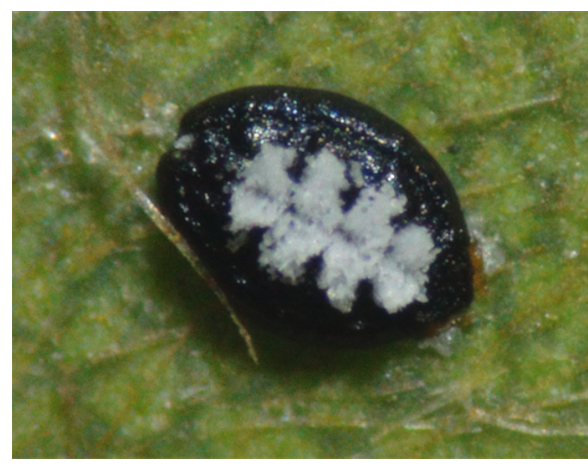

(a)

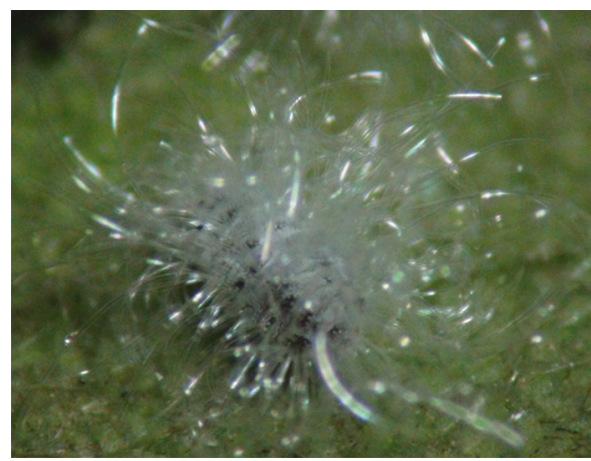

(c)

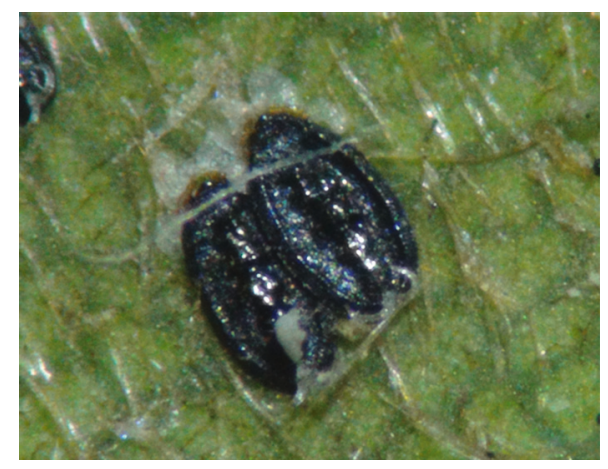

(b)

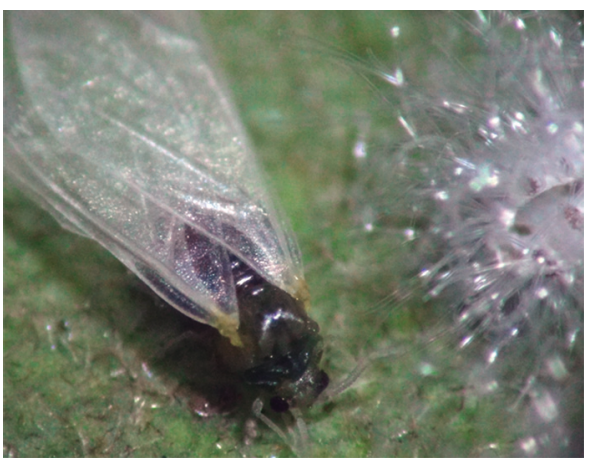

(d)

Figure 1: Neothoracaphis glaucae on the undersides of leaves of Quercus glauca found in Shinkiba, Tokyo, Japan: (a) an L-type apterous adult (20 January 2014); (b) two S-type apterous adults (20 January 2014); (c) a fourth-instar nymph to be alate (20 November 2013); (d) a teneral alate sexupara with a cast-off skin (20 November 2013).

D. racemosum in Tama and Hachioji in 2013 and 2014 and examined slide-mounted specimens of these nymphs.

2.5. Slide Preparation. Aphids preserved in $80 \%$ ethanol were cleared in cool or heated $10 \% \mathrm{KOH}$ solution. Nymphal aphids and alates were stained with Evans' blue and acid fuchsin, respectively, in approximately 50\% lactic acid. Almost all apterous adults were unstained. They were dehydrated in a mixture of glacial acetic acid and methyl salicylate for 1 day and mounted in balsam via a mixture of xylol-phenol and pure xylol.

2.6. Morphometry. Slide-mounted apterous adults of Neothoracaphis were examined and measured using a digital camera (FX630; Olympus, Tokyo, Japan) equipped with the image analysis software (FlvFs; Flovel, Tachikawa, Japan). The body length (from the head to the end of the eighth abdominal tergite) and the body width were measured for all specimens on collected leaves (Table 1) except for broken specimens without the eighth abdominal tergite and a few ill-mounted specimens. Since it was difficult to judge whether each aptera was alive at collection, broken aphids, which were certainly already dead, were not omitted so far as they could be measured. Approximately 140-220 apterous adults from six samples of the focal species, one sample of $N$. querciphaga, one sample of $N$. elongata, and one sample of N. yanonis were measured (Table 1). Because the sample of $N$. yanonis contained too many aphids, 191 apterae were randomly subsampled from it.

2.7. Data Analysis. The lengths and widths of apterous adults from the nine Neothoracaphis samples mentioned above were checked for normal distribution by the Kolmogorov-Smirnov test. When the null hypothesis of a normal distribution was rejected $(p<0.05)$, the data were further analyzed by Hartigans' dip test [12] under the null hypothesis of a unimodal distribution. All statistical analyses were performed with the software R v3.2.3 [13].

2.8. Examination of Specimens of Other Morphs. Many slidemounted specimens (including alates, apterous adults, firstinstar nymphs produced by the alates, and nymphs to be apterae and alates) were examined under a light microscope. Photographing of mounted specimens and the measurements for description were made using the digital camera equipped with the image analysis software mentioned in Section 2.6.

For elucidating the function of first-instar nymphs produced by alates of the focal species, the length of their stylets may be used as a cue to infer their feeding site. Although it was difficult to measure the precise length of stylets because of their tortuousness on the slide-mounted specimens, the length was estimated by approximating curves with a number of straight lines. The approximate length of 


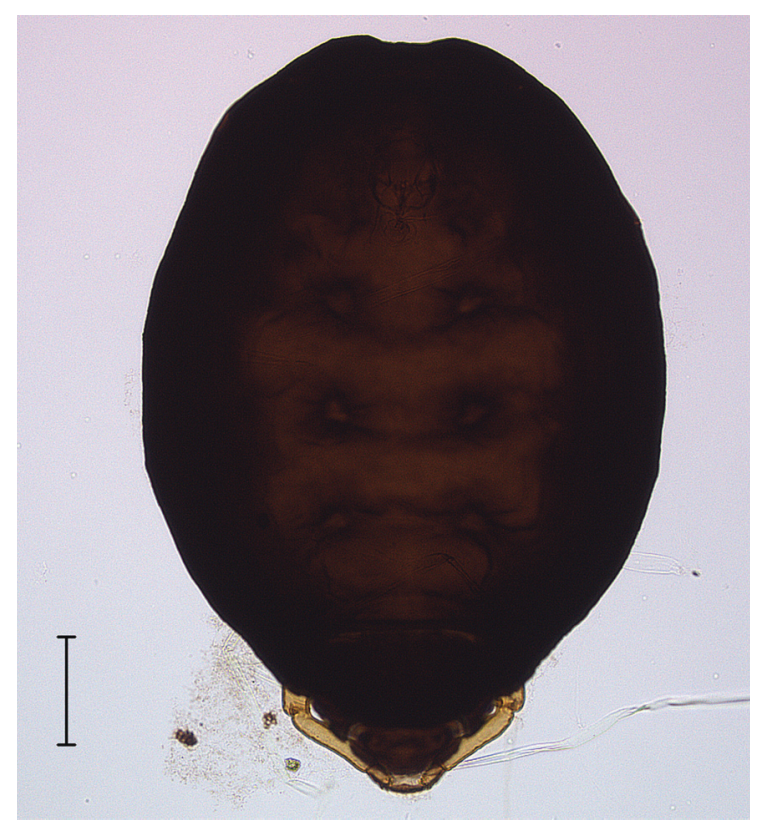

(a)

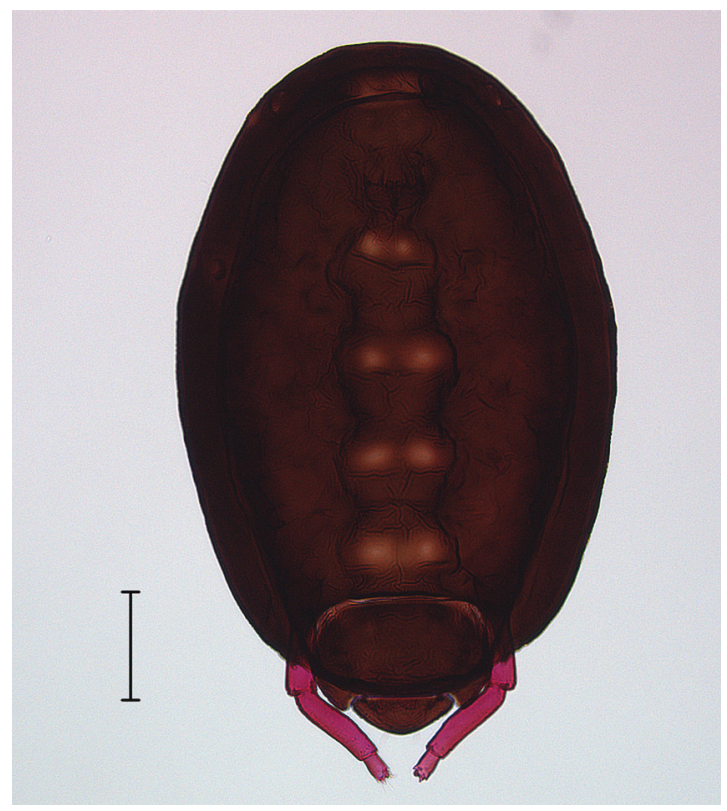

(c)

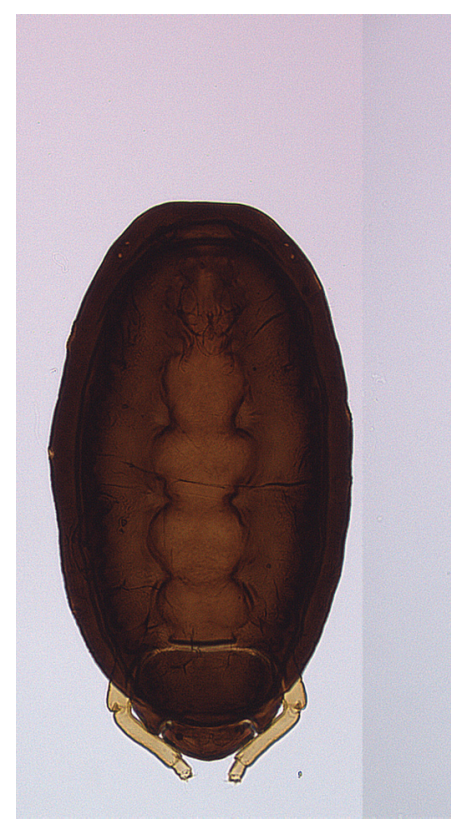

(b)

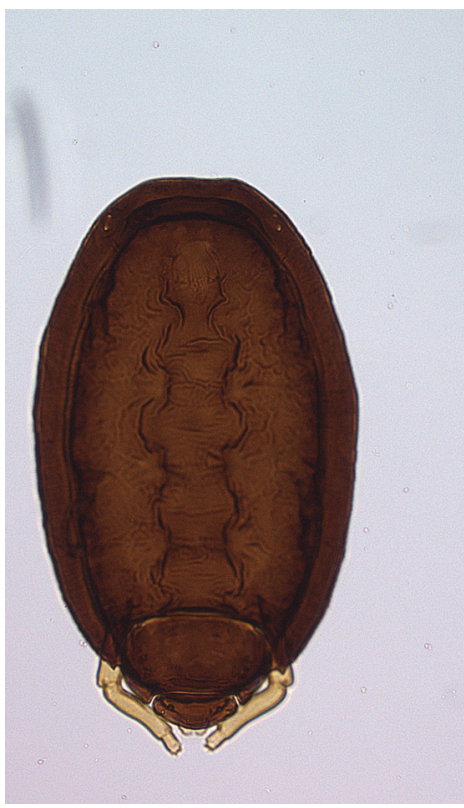

(d)

Figure 2: Apterous adults of Neothoracaphis: (a) L-type of N. glaucae (collected from Quercus glauca in Shinkiba, Tokyo, Japan, on 4 June 2014); (b) S-type of N. glaucae (collected from Q. glauca in Shinkiba, Tokyo, Japan, on 4 June 2014); (c) a large individual of N. querciphaga (collected from Q. myrsinifolia in Ome, Tokyo, Japan, on 6 May 2013); (d) a small individual of N. querciphaga (collected from Q. myrsinifolia in Ome, Tokyo, Japan, on 2 July 2014). Scale bars: $100 \mu \mathrm{m}$.

stylets was thus measured for 10 first-instar nymphs to be apterae of $N$. yanonis (feeding on leaves of Quercus serrata), 10 first- and five fourth-instar nymphs to be alate sexuparae of N. yanonis (feeding on leaves of Q. serrata), 10 first-instar females of $N$. yanonis (feeding on leaves of Distylium racemosum), nine first-instar males of $N$. yanonis (possibly nonfeeding on leaves of $D$. racemosum), 10 first-instar nymphs to be apterae of the focal species (feeding on leaves of Q. glauca), one first-instar nymph and 10 fourth-instar nymphs to be alates of the focal species (feeding on leaves of
Q. glauca), and 40 first-instar nymphs produced by alates of the focal species whose feeding plants/sites were unknown.

2.9. DNA Sequencing. Total DNA was extracted from each of fresh or fixed insects using QIAamp Tissue Kit (Qiagen, Hilden, Germany). From the insect DNA, a $1.6 \mathrm{kB}$ mitochondrial DNA fragment containing small subunit rRNA, tRNA-Val, and large subunit rRNA genes was amplified by PCR using two primers, MtrA1 (5'-AAWAAACTAGGATTAGATACCCTA-3 $\left.{ }^{\prime}\right)$ and 
TABle 1: Samples of Neothoracaphis species subjected to morphometric analysis.

\begin{tabular}{|c|c|c|c|c|c|c|c|}
\hline Species & $\begin{array}{l}\text { Sample } \\
\text { code }\end{array}$ & $\begin{array}{l}\text { Collection } \\
\text { date }\end{array}$ & Collection locality $^{\dagger}$ & $\begin{array}{c}\text { Host species of } \\
\text { Quercus }\end{array}$ & $\begin{array}{c}\text { No. of leaves } \\
\text { sampled }\end{array}$ & $\begin{array}{c}\text { No. of mounted } \\
\text { specimens }\end{array}$ & $\begin{array}{c}\text { No. of specimens } \\
\text { measured }\end{array}$ \\
\hline N. glaucae & $\# 14008$ & 20.1 .2014 & Shinkiba, Tokyo & Q. glauca & 2 & 196 & 160 \\
\hline N. glaucae & \#14071 & 28.3.2014 & Shinkiba, Tokyo & Q. glauca & 6 & 208 & 189 \\
\hline N. glaucae & \#14117 & 4.6.2014 & Shinkiba, Tokyo & Q. glauca & 3 & 235 & 219 \\
\hline N. glaucae & \#13117 & 17.9.2013 & Shinkiba, Tokyo & Q. glauca & 2 & 198 & 167 \\
\hline N. glaucae & $\# 14172$ & 5.11 .2014 & Shinkiba, Tokyo & Q. glauca & 3 & 156 & 146 \\
\hline N. glaucae & \#14115 & 4.6.2014 & Shinkiba, Tokyo & Q. glauca & 3 & 148 & 143 \\
\hline $\begin{array}{l}N . \\
\text { querciphaga }\end{array}$ & $\# 14122$ & 2.7.2014 & Ome, Tokyo & Q. myrsinifolia & 22 & 189 & 154 \\
\hline N. elongata & \#17115 & 5.11 .2017 & $\begin{array}{l}\text { Tanegashima Island, } \\
\text { Kagoshima Prefecture }\end{array}$ & Q. acuta & 2 & 174 & 123 \\
\hline N. yanonis & $\# 13127$ & 9.10 .2013 & Tama, Tokyo & Q. serrata & 1 & $191^{\S}$ & 175 \\
\hline
\end{tabular}

${ }^{\dagger}$ All collection localities are in Japan; ${ }^{\ddagger}$ sampled from new leaves; ${ }^{\circledR}$ subsampled.

TABLE 2: Aphid samples subjected to DNA sequencing.

\begin{tabular}{|c|c|c|c|c|}
\hline Insect sample & Collection locality $^{\dagger}$ & $\begin{array}{l}\text { Collection } \\
\text { date }\end{array}$ & Host plant & $\begin{array}{l}\text { Accession } \\
\text { no. }^{\ddagger}\end{array}$ \\
\hline $\begin{array}{l}\text { Neothoracaphis glaucae: L-type } \\
(\# 13040)\end{array}$ & Ome, Tokyo & 6.5 .2013 & Quercus glauca & $\mathrm{LC}^{2} 87692^{\S}$ \\
\hline N. glaucae: S-type (\#13041) & Ome, Tokyo & 6.5 .2013 & Quercus glauca & $\mathrm{LC} 487693^{\S}$ \\
\hline N. glaucae: S-type (\#13010) & Shinkiba, Tokyo & 8.2 .2013 & Quercus glauca & LC487694 \\
\hline $\begin{array}{l}\text { N. glaucae: wingpadded nymph } \\
(\# 13154)\end{array}$ & Shinkiba, Tokyo & 1.11 .2013 & Quercus glauca & LC487695 \\
\hline $\begin{array}{l}\text { N. glaucae: wingpadded nymph } \\
(\# 13187)\end{array}$ & Shinkiba, Tokyo & 14.11 .2013 & Quercus glauca & LC487696 \\
\hline N. glaucae: S-type (\#18078) & Takao, Tokyo & 16.5 .2018 & Quercus glauca & LC487697 \\
\hline N. glaucae: L-type (\#18079) & Takao, Tokyo & 16.5 .2018 & Quercus glauca & LC487698 \\
\hline N. glaucae: S-type (\#18082) & Kitakyushu, Fukuoka Prefecture & 16.6.2018 & Quercus myrsinifolia & LC487699 \\
\hline N. glaucae: S-type (\#18098) & Yugawara, Kanagawa Prefecture & 29.7.2018 & Quercus myrsinifolia & LC487700 \\
\hline N. elongata (\#17093) & $\begin{array}{c}\text { Tanegashima Island, Kagoshima } \\
\text { Prefecture }\end{array}$ & 5.11 .2017 & Quercus acuta & $\mathrm{LC} 87701^{\S}$ \\
\hline N. elongata (\#19005) & Shiba, Tokyo & 8.1.2019 & Quercus acuta & $\mathrm{LC} 487702^{\S}$ \\
\hline N. querciphaga: L-type (\#13035) & Ome, Tokyo & 6.5 .2013 & Quercus myrsinifolia & $\mathrm{LC} 487703^{\mathrm{S}}$ \\
\hline N. querciphaga: S-type (\#13037) & Ome, Tokyo & 6.5 .2013 & Quercus myrsinifolia & LC487704 \\
\hline N. querciphaga: L-type (\#18047) & Hachioji, Tokyo & 26.3.2018 & Quercus myrsinifolia & $\mathrm{LC} 487705^{\S}$ \\
\hline N. querciphaga: S-type (\#18048) & Hachioji, Tokyo & 26.3.2018 & Quercus myrsinifolia & $\mathrm{LC} 487706^{\S}$ \\
\hline N. yanonis (\#17084) & $\begin{array}{c}\text { Tanegashima Island, Kagoshima } \\
\text { Prefecture }\end{array}$ & 3.11 .2017 & Quercus dentata & $\mathrm{LC} 487691^{\S}$ \\
\hline N. yanonis (Gall_Mie204) & Tsu, Mie Prefecture & 6.5 .1996 & $\begin{array}{l}\text { Distylium } \\
\text { racemosum }\end{array}$ & LC487689 \\
\hline N. yanonis (Gall_Tokyo46) & Shinkiba, Tokyo & May 2003 & $\begin{array}{l}\text { Distylium } \\
\text { racemosum }\end{array}$ & LC487690 \\
\hline
\end{tabular}

${ }^{\dagger}$ All collection localities are in Japan. ${ }^{*}$ DNA sequences are deposited in the DDBJ/EMBL/GenBank nucleotide sequence database. ${ }^{\S}$ Slide-mounted aphids from the same colony are deposited in the collection of Systematic Entomology, Hokkaido University (Sapporo, Japan), as voucher specimens.

MtrB1 (5'-TCTTAATYCAACATCGAGGTCGCAA-3'), under the temperature profile of $95^{\circ} \mathrm{C}$ for $10 \mathrm{~min}$ followed by 40 cycles of $94^{\circ} \mathrm{C}$ for $1 \mathrm{~min}, 48^{\circ} \mathrm{C}$ for $1 \mathrm{~min}$, and $65^{\circ} \mathrm{C}$ for $3 \mathrm{~min}$. The amplified DNA fragment was purified using exonuclease I (New England Biolabs, Massachusetts, USA) and alkaline phosphatase (shrimp) (Takara Bio, Shiga, Japan) at $37^{\circ} \mathrm{C}$ for $15 \mathrm{~min}$ followed by $80^{\circ} \mathrm{C}$ for $15 \mathrm{~min}$ and directly subjected to a sequencing reaction with BigDye Terminator v3.1 Cycle Sequencing Kit (Thermo Fisher Scientific, Massachusetts, USA). In addition to MtrA1 and MtrB1 primers, the following internal primers were used for sequencing: MtrA2 $\left(5^{\prime}-\right.$ ACAAAGTAARTGTACTGGAAAGTGT-3 $\left.{ }^{\prime}\right), \operatorname{MtrA3}\left(5^{\prime}-\right.$
ATTTTYATCTGTTTAACAAAAACAT-3'), MtrA4 (5'AGAYAAGTCGTAACAWAGTA-3'), MtrA5 (5'-AATAGCTGCAGTATTTTRACTGT-3'), MtrB2 (5'-TTAATACAATGTTTTTGTTAAACAG-3' $\left.3^{\prime}\right)$, MtrB3 (5'-ACACTTTCCAG TACAYTTACTTTGT-3 $\left.{ }^{\prime}\right)$, MtrB4 (5' ${ }^{\prime}$ TACTWTGTTACGAC TTRTCT-3'), and MtrB5 (5' -ACAGTYAAAATACTGCAGCT ATT $\left.-3^{\prime}\right)$, under a temperature profile of $94^{\circ} \mathrm{C}$ for $2 \mathrm{~min}$ followed by 30 cycles of $94^{\circ} \mathrm{C}$ for $1 \mathrm{~min}, 48^{\circ} \mathrm{C}$ for $2 \mathrm{~min}$, and $65^{\circ} \mathrm{C}$ for $3 \mathrm{~min}$. The reaction products were analyzed with the Genetic Analyzer (3130xl; Applied Biosystems, Foster, CA, USA). The accession numbers of the DNA sequences determined in this study are listed in Table 2. 


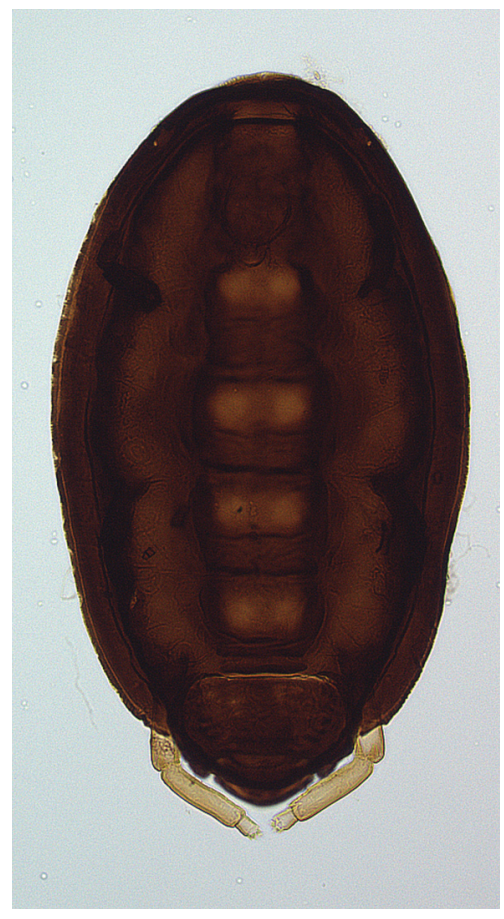

(a)

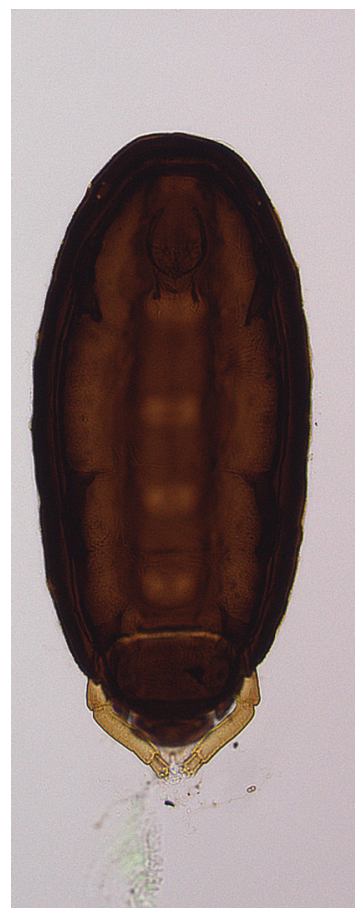

(b)

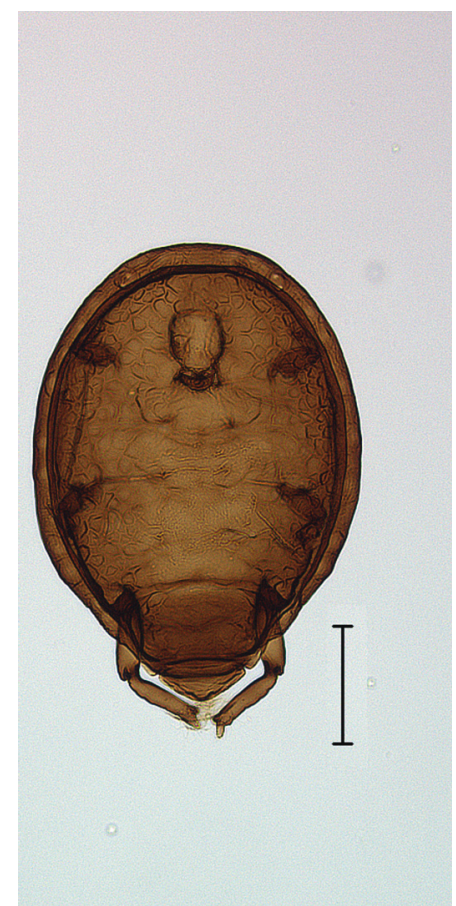

(c)

Figure 3: Apterous adults of Neothoracaphis: (a) a large individual of N. elongata (collected from Quercus acuta in Tanegashima Island, Kagoshima Prefecture, Japan, on 5 November 2017); (b) a small individual of N. elongata (collected from Q. acuta in Shiba, Tokyo, Japan, on 8 December 2018); (c) N. yanonis (collected from Q. serrata in Tama, Tokyo, Japan, on 9 October 2013). Scale bar: $100 \mu \mathrm{m}$.

2.10. Molecular Phylogenetic Analysis. The DNA sequences of the Neothoracaphis species determined in this study (Table 2) and those we had already reported in the study of Kurosu et al. [14] were subjected to the molecular phylogenetic analyses. A multiple alignment of the nucleotide sequences was generated by using the program package Muscle implemented in MEGA version $7[15,16]$. Aligned nucleotide sites containing gaps were removed from the dataset to generate a reliable alignment. The model selection and molecular phylogenetic analyses by maximum likelihood (ML) methods were also performed by MEGA version 7. The GTR $+\mathrm{G}+\mathrm{I}$ model was selected as the nucleotide substitution model for the aligned sequences on the basis of the Bayesian information criterion [17]. Bootstrap tests were performed with 1,000 replications. Sixteen nipponaphidines, Dermaphis coccidiformis, D. autumna, D. japonensis, D. crematogastri, Monzenia globuli, Metanipponaphis cuspidatae, $M$. rotunda, Nipponaphis distyliicola, N. monzeni, N. loochooensis, N. distychii, N. machilicola, Allothoracaphis piyananensis, Metathoracaphis isensis, Quernaphis tuberculata, and Quadrartus yoshinomiyai, were also subjected to the analysis, and Ceratovacuna nekoashi (Hormaphidinae, Cerataphidini) was used as an outgroup. The nucleotide sequences of these species had already been deposited in the DNA Data Bank of Japan [18-21]; the accession numbers are indicated in Figure 6.

\section{Results}

3.1. Molecular Phylogenetic Analyses. The result of our molecular phylogenetic analysis based on mitochondrial ribosomal DNA sequences is summarized as the maximum likelihood tree (Figure 6). We found that all samples of Neothoracaphis species formed a monophyletic group with $87 \%$ bootstrap support and that both four samples of $N$. yanonis and the remaining 15 samples of the other Neothoracaphis species formed monophyletic groups with 100\% bootstrap support. Two samples, \#13040 and \#13041, S-type and L-type apterae of the focal species collected from a single tree of Quercus glauca, had completely identical nucleotide sequences. Another two samples, \#18078 (S-type) and \#18079 (L-type), from a single tree of Q. glauca had almost identical nucleotide sequences except for a 6-bp insertion in \#18078, which were removed from the dataset for the molecular phylogenetic analyses as described in Section 2.10. This indicated that the two types of apterous adults, or what have been called " $N$. saramaoensis" and "N. glaucae," are different phenotypes of one and the same species. For the reason discussed later (Section 4.1), we hereafter use the name $N$. glaucae for this species. Eight samples of the focal species, including one sample from Q. myrsinifolia (\#18082) and two wingpadded nymphs (\#13154 and \#13187), had almost identical nucleotide sequences and formed a monophyletic group with 100\% bootstrap support. The remaining one sample collected from Q. myrsinifolia (\#18098) had a slightly different sequence from those of the eight samples, but they together formed a monophyletic group with $68 \%$ bootstrap support. No reliable morphological differences were found between them.

The samples of $N$. elongata and $N$. querciphaga each formed a monophyletic group with $100 \%$ bootstrap support. Also in $N$. querciphaga, the nucleotide sequences of small 


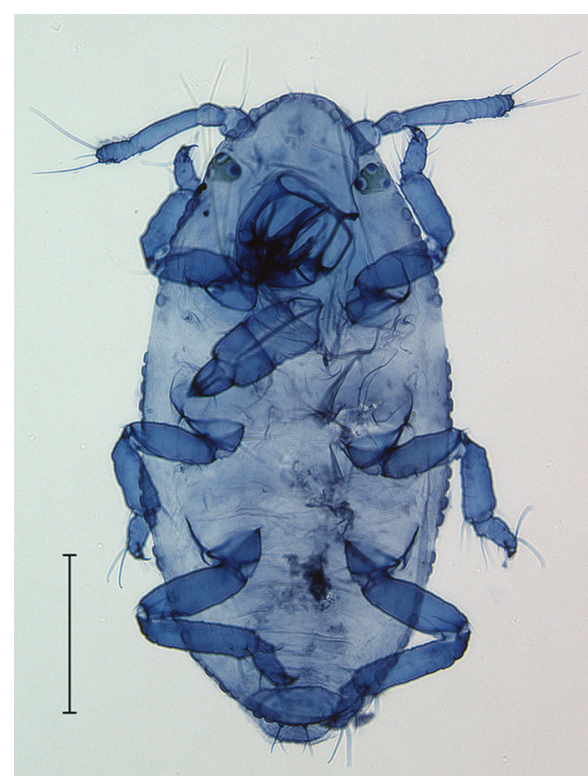

(a)

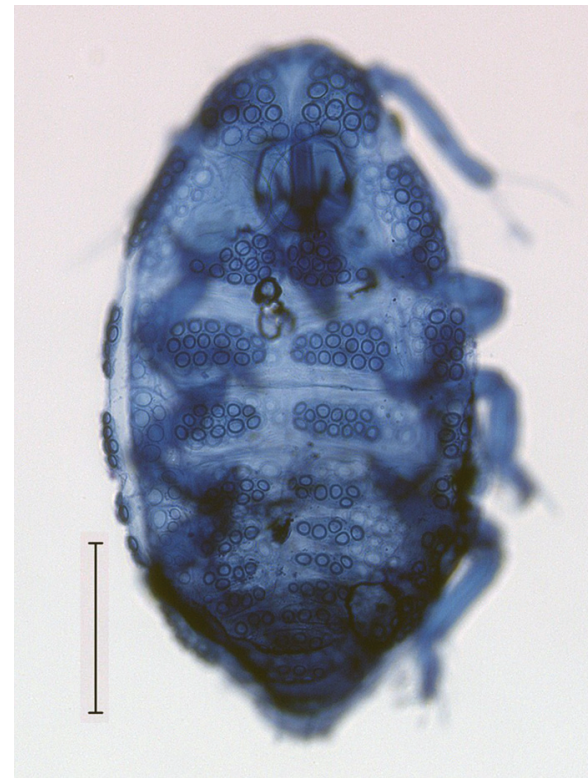

(c)

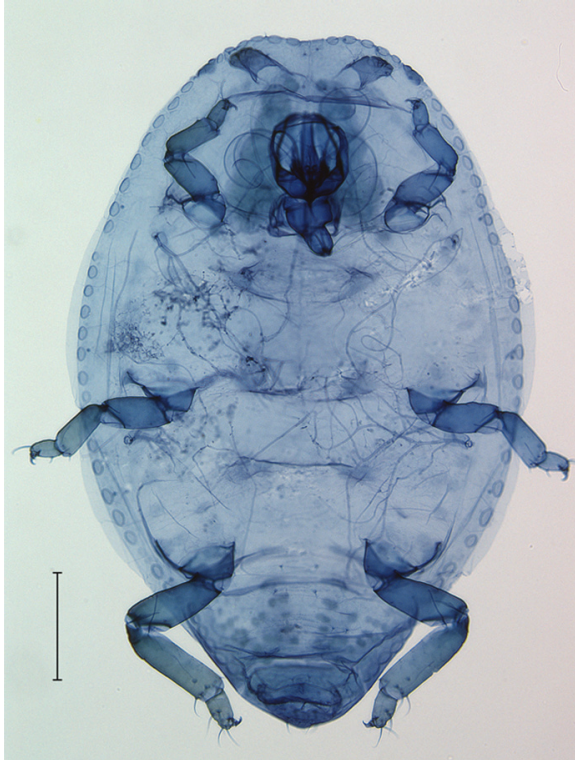

(b)

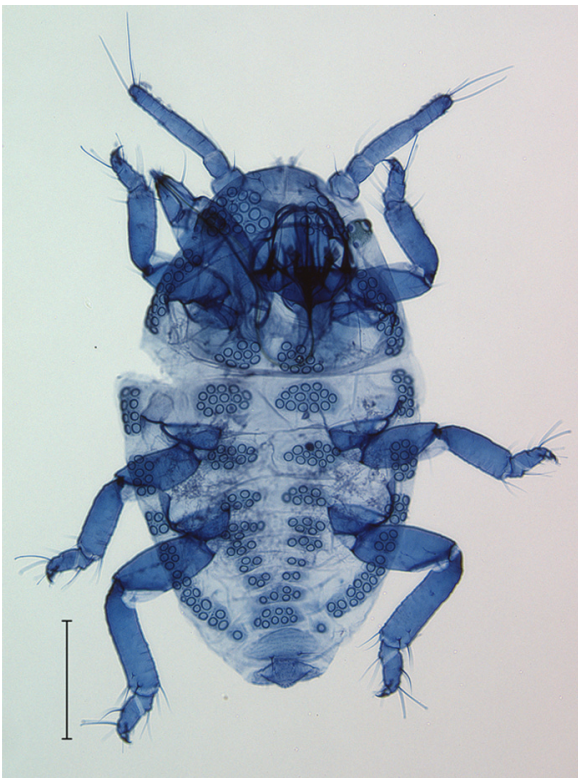

(d)

Figure 4: Nymphs of Neothoracaphis glaucae: (a) first-instar nymph to be aptera (collected on 5 November 2014); (b) nonfirst (probably third) instar nymph to be aptera (collected on 8 February 2013); (c) first-instar nymph to be alate (collected on 1 November 2013); (d) firstinstar nymph produced by the alate (fixed on 1 December 2013). All aphids were collected from Quercus glauca in Shinkiba, Tokyo, Japan. Scale bars: $100 \mu \mathrm{m}$.

and large individuals (\#18047 and \#18048; \#13035 and \#13037) were almost identical, except for a 2-bp insertion in $\# 18047$ and \#13037. Among the three species, however, it was not conclusively determined which two are more closely related to each other.

3.2. Morphometric Analyses. The body length and width of apterous adults in six samples of the focal species, N. glaucae, which were collected from Q. glauca in Shinkiba, Tokyo, in January, March, June (from old and new leaves), September, and November (Table 1), are shown as scatter diagrams in Figure 7 (Figures S1-S5). There was large variation in the sizes of apterous adults of the January, March, and June (from old leaves) samples, in comparison with those of N. yanonis, N. elongata, and N. querciphaga (Figure 8). This is because these samples contained many L-type (large) apterous adults in addition to S-type (small) apterous adults. While S-type apterous adults were abundantly contained in all six samples, or were abundantly found throughout the year, L-type apterous adults were few in the September and November samples (\#13117 and \#14172). The tendency is 


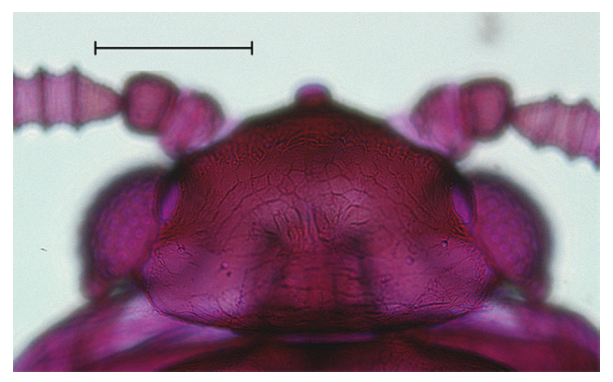

(a)

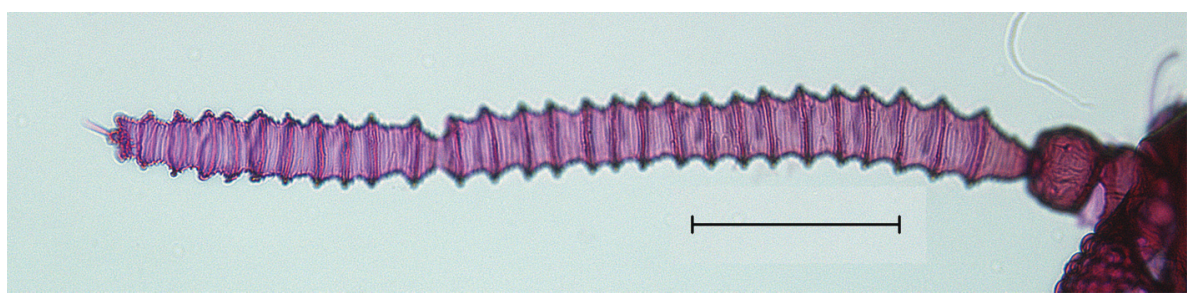

(c)

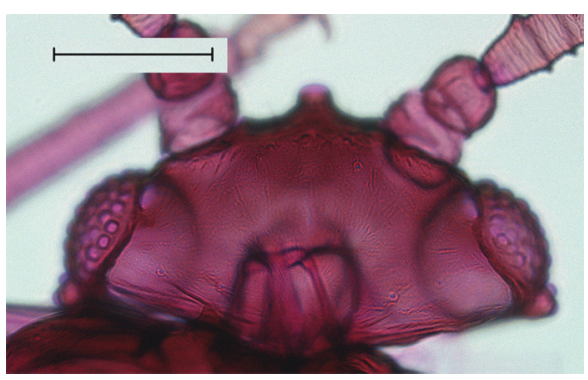

(b)

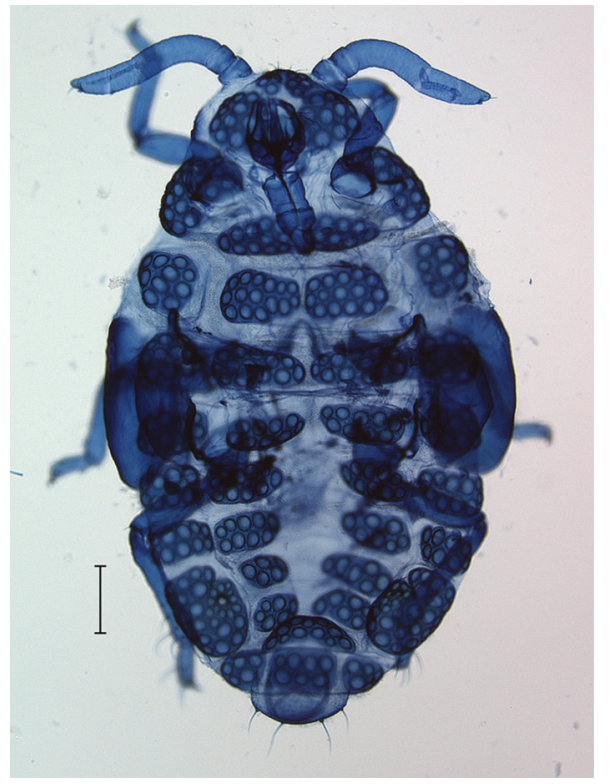

(d)

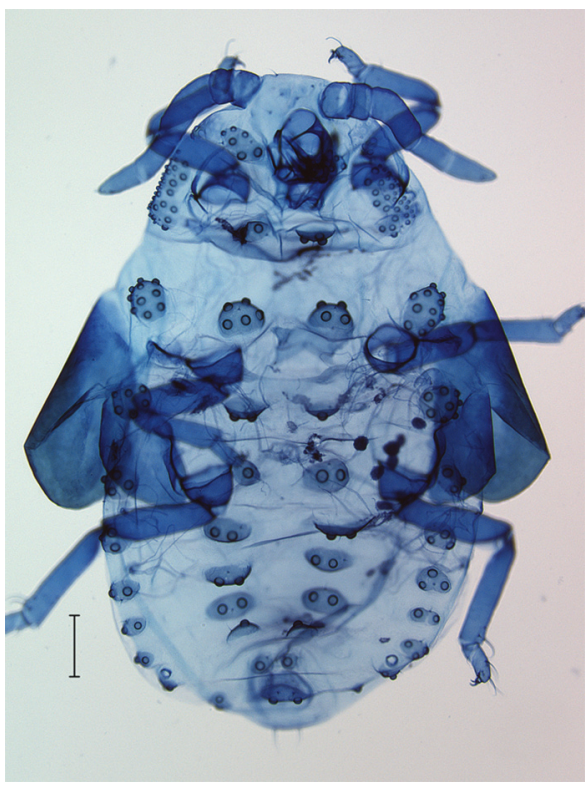

(e)

Figure 5: Alates and wingpadded nymphs of Neothoracaphis glaucae and N. yanonis: (a) head of the alate of N. glaucae (collected from Q. glauca as a nymph in Shinkiba, Tokyo, Japan, on 25 November 2013 and fixed on 8 December 2013); (b) head of the alate of N. yanonis (collected from Distylium racemosum in Tama, Tokyo, on 20 November 2013); (c) left antenna of the alate of N. glaucae (collected from Q. glauca as a nymph in Shinkiba on 14 November 2013 and fixed on 26 November 2013); (d) fourth-instar nymph of N. glaucae (collected from Q. glauca in Shinkiba on 14 November 2013); (e) fourth-instar nymph of N. yanonis (collected from Q. serrata in Tama on 1 December 2013). Scale bars: $100 \mu \mathrm{m}$.

manifested in the smaller mean and CV of body lengths in the September and November samples (Table 3). If we operationally define L-type apterae as those with the body width being larger than $390 \mu \mathrm{m}$, the percentage of L-type apterae in the latter two samples is less than 1.5 (Table 3). All 222 apterous adults sampled from new leaves, including 143 apterae of sample \#14115 (Table 3; Figure S5), were of S-type.

In the three samples collected in January, March, and June (\#14008, \#14071, and \#14117), the null hypothesis of a normal distribution was rejected for both the body lengths and body widths ( $p \ll 0.01$ ), while it was not for either in the remaining three samples of $N$. glaucae. The frequency distribution diagrams for body lengths and widths of the March sample (\#14071) exhibit bimodal distributions (Figure 7). The null hypothesis of a unimodal distribution was rejected for the body widths (Hartigans' dip test; $p \ll 0.01$ ), but not for the body lengths $(p=0.059)$. In the March sample, the frequency distribution for the ratio of the body width to the body length also exhibits a clear bimodal pattern (Hartigans' dip test; $p \ll 0.01$ ).

Although there was considerable variation in the body size and shape of N. querciphaga (Figures 2(c) and 2(d)) and 


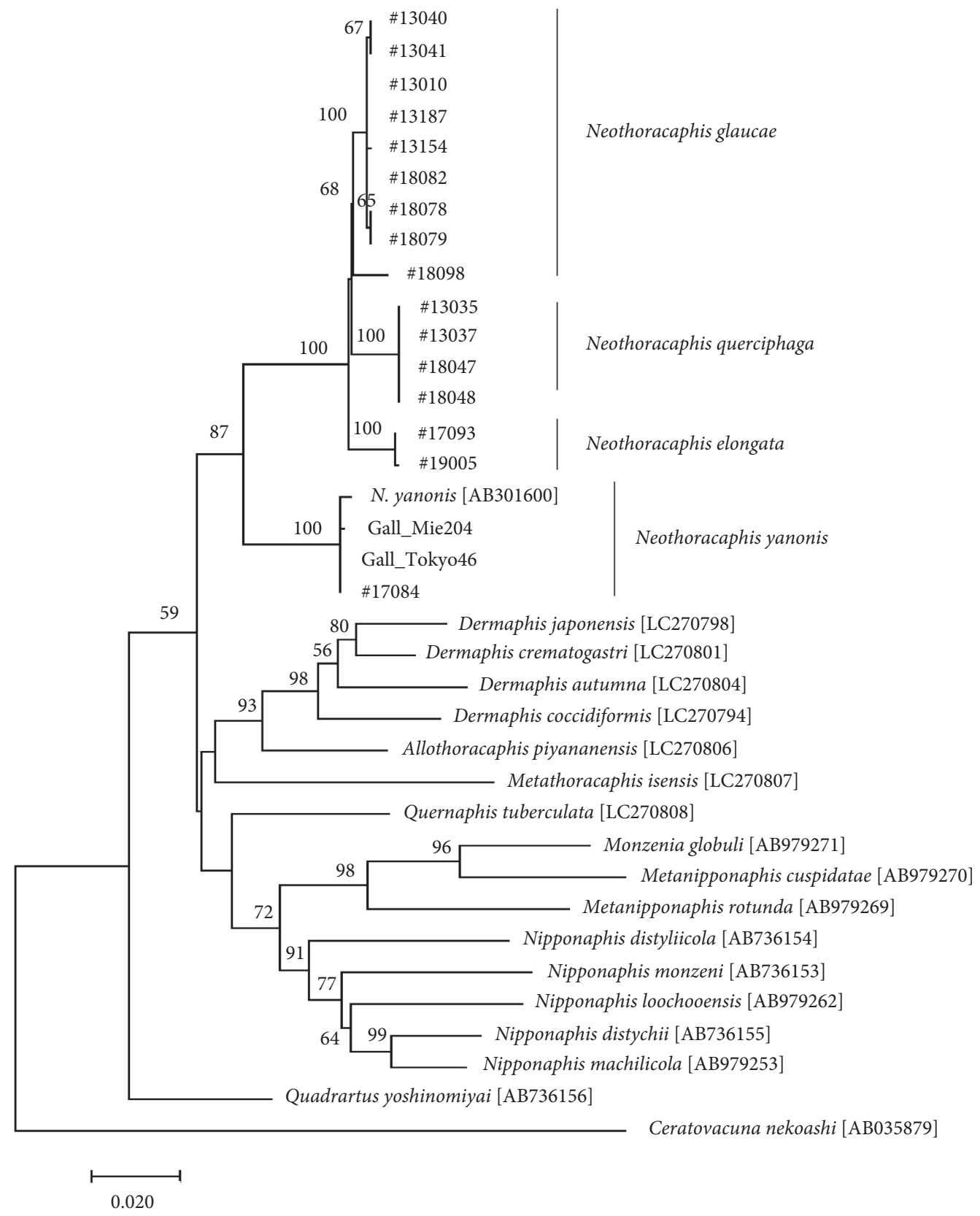

FIgURE 6: The maximum likelihood (ML) phylogeny of nipponaphidines including four Neothoracaphis species inferred from unambiguously aligned 1,520 nucleotide sites of their mitochondrial rRNA gene sequences. Bootstrap values higher than $50 \%$ are indicated on the nodes.

N. elongata (Figures 3(a) and 3(b)), the samples did not show clear bimodal distributions (Figure 8). The null hypothesis of a normal distribution was rejected neither for the body lengths nor for the body widths in the sample of $N$. yanonis, only for the body lengths $(p=0.023)$ in the sample of $N$. querciphaga, and only for body widths $(p=0.006)$ in the sample of $N$. elongata. The null hypothesis of a unimodal distribution was not rejected for any data of the three species.

3.3. Morphology of Other Morphs. Photos of slide-mounted specimens of the following phenotypes of $N$. glaucae are shown as figures: first-instar nymph that develops into aptera (Figure 4(a)), nonfirst (probably third) instar nymph that develops into aptera (Figure 4(b)), first- and fourthinstar nymphs that develop into alates (Figures 4(c) and 5(d)), and first-instar nymph produced by the alate (Figure 4(d)). Also, those of the following phenotypes of $N$. yanonis are shown as figures: first-instar nymph that develops into aptera (Figure 9(a)), first- and fourth-instar nymphs that develop into alates (Figures 9(b) and 5(e)), firstinstar male (Figure 9(c)), and first-instar (sexual) female (Figure 9(d)). In either species, first-instar nymphs to be apterae had only marginal wax plates and no spinal row of 


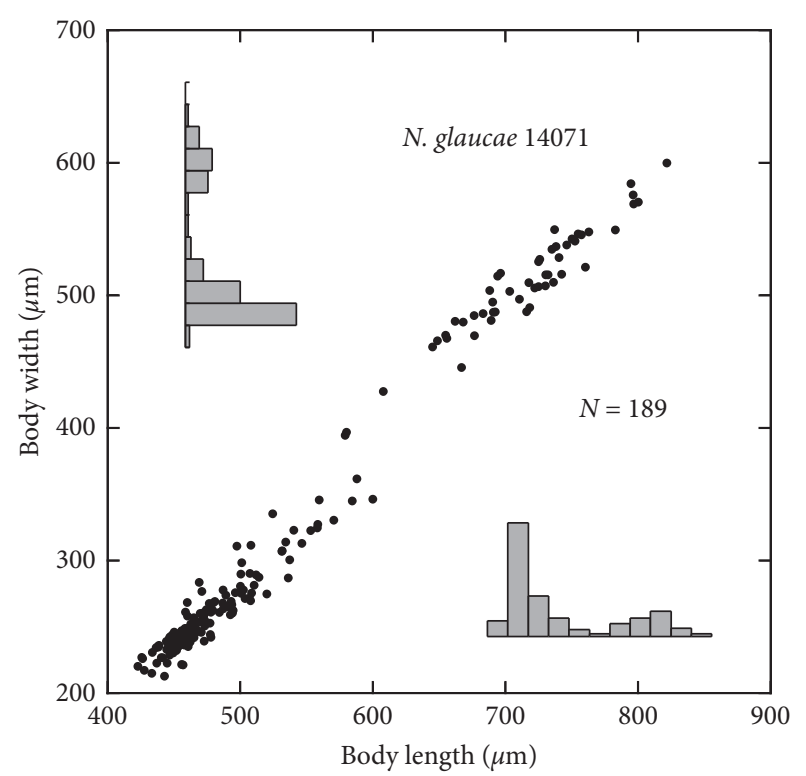

Figure 7: Scatter diagram of body length versus body width for apterous adults of Neothoracaphis glaucae (sample \#14071), with frequency distribution diagrams of the body lengths and widths ( $40 \mu \mathrm{m}$ for 1 unit of the axis).

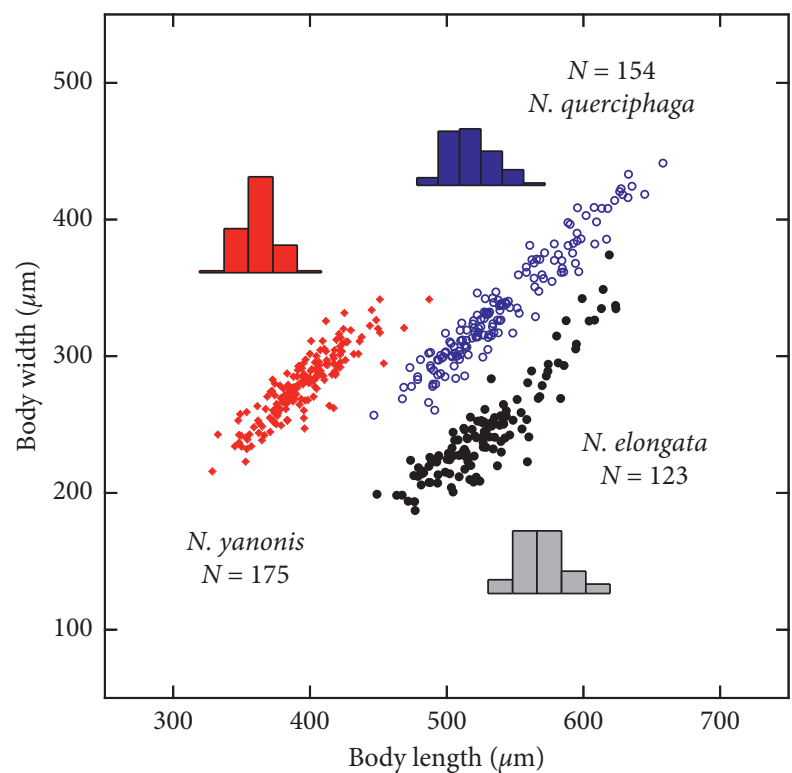

Figure 8: Scatter diagram of body length versus body width for apterous adults of Neothoracaphis yanonis (red squares), $N$. querciphaga (blue open circles), and N. elongata (black closed circles), each with a frequency distribution diagram of the body lengths ( $40 \mu \mathrm{m}$ for 1 unit of the axis).

wax plates, whereas first-instar nymphs to be alates had spinal rows of wax plates.

First-instar nymphs to be apterae of $N$. glaucae (Figure 4(a)) had well-developed setae on the tips of antennae and the tarsi, whereas later-instar nymphs to be apterae had reduced antennae and reduced tarsi with shorter setae (Figure 4(b)). This suggests that the first-instar nymphs are likely to be dispersers within a tree, or even between trees.
In N. yanonis, first-instar females and males were clearly distinguished from each other. The main morphological differences found between sexes are summarized in Table 4 . The adult females of $N$. yanonis had a pair of ring-like cornicles on the posterior abdominal tergites [8], while the adult males lacked them (Figure S6). First-instar sexuals lacked cornicles, but in the female, cornicles appeared from the second instar onward. We could therefore determine which of the two morphs were of the female by examining pharate first-instar sexuals (first-instar sexuals with the second-instar cuticle developing inside). Contrary to the sexual dimorphism in the adult, the males (Figure 9(c)) were larger than the females (Figure 9(d)) in the first instar (Table 4).

The approximate lengths of stylets of the nymphs of $N$. yanonis and N. glaucae are shown in Table 5. First-instar nymphs of $N$. yanonis to be apterae and first- and fourthinstar nymphs of N. yanonis to be alates, which were feeding on leaves of Quercus serrata, had stylets that were approximately $0.10-0.13 \mathrm{~mm}$ in length. First-instar (sexual) females of $N$. yanonis, which were feeding on leaves of Distylium racemosum, had stylets that were $0.21-0.23 \mathrm{~mm}$ long, longer than the stylets of the nymphs feeding on leaves of Q. serrata. First-instar males of N. yanonis on leaves of D. racemosum had short stylets that were $0.06-0.10 \mathrm{~mm}$, suggesting that they could mature without taking food. Firstinstar nymphs of $N$. glaucae to be apterae and a first-instar nymph and fourth-instar nymphs of N. glaucae to be alates, which were feeding on leaves of Q. glauca, had stylets that were $0.14-0.18 \mathrm{~mm}$ long. First-instar nymphs produced by alates of $N$. glaucae in glass vials had stylets that were $0.25-0.29 \mathrm{~mm}$ long, which were clearly longer than the stylets of the nymphs feeding on leaves of Q. glauca.

Because alates of $N$. glaucae were found for the first time, they are described in the next section.

3.4. Description of Alates of Neothoracaphis glaucae. Unless the sample size is indicated in parentheses, the following description is based on 10 specimens which were collected as nymphs from leaves of Quercus glauca in Shinkiba on 14 and 25 November 2013 and emerged in the laboratory between 26 November and 8 December 2013.

The body is $1.0-1.3$ (mean 1.2) $\mathrm{mm}$ long. The head is $0.27-0.33(0.30) \mathrm{mm}$ wide across the compound eyes, weakly rugose, or reticulate on the dorsum (Figure 5(a)), ventrally with four minute setae between the bases of antennal sockets. The antenna (Figure 5(c)) is five-segmented: the segment III is 232-307 (269) $\mu \mathrm{m}$ long, longer than the fore tibia, 1.7-2.4 (1.9) times as long as the length of the segments IV and V combined; the segment IV is $68-93$ (82) $\mu \mathrm{m}$ long; and the segment $\mathrm{V}$ is shorter than IV, 49-68 (57) $\mu \mathrm{m}$ long. The processus terminalis is very short, with two apical setae which are about as long as the diameter of the segment at the base. Secondary rhinaria are narrow, often encircling the circumference of the segment; the segments III, IV, and V are with 13-18 (15), 5-7 (6), and 3-5 (4) secondary rhinaria, respectively. The primary rhinarium on the segment IV is indistinct, united with the distal secondary rhinarium; the 
TABLE 3: Body lengths of Neothoracaphis apterous adults.

\begin{tabular}{|c|c|c|c|c|c|c|c|}
\hline \multirow{2}{*}{ Species } & \multirow{2}{*}{ Sample code } & \multicolumn{5}{|c|}{ Length of the body in $\mu \mathrm{m}$} & \multirow{2}{*}{ L-type apterae ${ }^{\dagger}, N(\%)$} \\
\hline & & $N$ & Min. & Max. & Mean & $\mathrm{CV}$ & \\
\hline N. glaucae & $\# 14008^{\#, \S}$ & 160 & 410 & 844 & 543 & 0.16 & $22(13.8)$ \\
\hline N. glaucae & $\# 14071^{\ddagger, \S, 9}$ & 189 & 423 & 822 & 541 & 0.21 & $51(27.0)$ \\
\hline N. glaucae & $\# 14117^{\ddagger, \S}$ & 219 & 425 & 775 & 536 & 0.13 & $23(10.5)$ \\
\hline N. glaucae & \#13117 & 167 & 420 & 677 & 526 & 0.08 & $2(1.2)$ \\
\hline N. glaucae & \#14172 & 146 & 411 & 686 & 503 & 0.10 & $2(1.4)$ \\
\hline N. glaucae & \#14115 & 143 & 428 & 543 & 480 & 0.05 & 0 \\
\hline N. querciphaga & $\# 14122^{*}$ & 154 & 447 & 658 & 540 & 0.08 & $18(11.7)$ \\
\hline N. elongata & $\# 17115^{\S}$ & 123 & 449 & 624 & 529 & 0.07 & 0 \\
\hline N. yanonis & \#13127 & 175 & 329 & 487 & 395 & 0.07 & 0 \\
\hline
\end{tabular}

${ }^{\dagger} \mathrm{L}$-type apterae are operationally defined as those with the body width larger than $390 \mu \mathrm{m}$. ${ }^{*}$ The null hypothesis of a normal distribution is rejected for the body lengths. ${ }^{5}$ The null hypothesis of a normal distribution is rejected for the body widths. ${ }^{5}$ The null hypothesis of a unimodal distribution is rejected for the body widths.

primary rhinarium on the segment $\mathrm{V}$ is ciliated, often united with the distal secondary rhinarium. The ultimate rostral segment is $41-50(46) \mu \mathrm{m}$ long $(n=8)$, without secondary setae. The legs are slender; the fore tibia is 206-255 (232) $\mu \mathrm{m}$ long, and the hind femorotrochanter is 202-235 (217) $\mu \mathrm{m}$ long. Tarsi are two-segmented: the segment I is with a pair of long, spatulate setae and one shorter seta on fore- and midlegs, and the segment II is 58-67 (63) $\mu \mathrm{m}(n=9)$ on the hind leg, middorsally with a pair of pointed setae and apically with three pairs of setae, of which the dorsoapical and lateroapical setae are long and widened at the apex and the ventroapical setae are short and pointed; empodial setae are spatulate at the apex, reaching the apices of the claws. The forewing is with two branches of the media which usually are not connected, and the basal vein of the media is indistinct. The abdomen is with two pairs of sclerotized spiracles, and with a pair of ring-like cornicles which are $18-22(20) \mu \mathrm{m}$ in outer diameter. The abdominal tergite VII is membranous, mesially with two setae; the tergite VIII is weakly sclerotized, with four rather long setae. The cauda is small, 28-36 (32) $\mu \mathrm{m}$ wide, with 7-9 (8) setae. The anal plate is bilobed, with a total of 10-14 (12) setae. The genital plate is with 2-5 (4) setae anteriorly and 8-12 (10) setae along the posterior margin $(n=9)$.

The alates of $N$. glaucae were, in morphology, similar to those of $N$. yanonis, a description of which is given by Takahashi [8]. The former were discriminated from the latter in having the head with reticulated sculptures (Figure 5(a)); the head of $N$. yanonis was smooth on the dorsum (Figure 5(b)). Fourth-instar nymphs (to be alates) of the two species were easily discriminated from each other by their wax plates on the tergites (Figures 5(d) and 5(e)).

\section{Discussion}

4.1. Identity of Neothoracaphis glaucae and N. saramaoensis. Our molecular phylogenetic analyses clearly indicated that what have been called "Neothoracaphis saramaoensis" and "N. glaucae" are in reality two different phenotypes of a single species. The former name was given by Takahashi [22] in 1935 (as Thoracaphis saramaoensis) and the latter by Takahashi [8] in 1958 (as Microthoracaphis glaucae). Taking the present result in advance, Miyazaki et al. [23] adopted $N$. saramaoensis as the valid name for this species and regarded the name $N$. glaucae as a junior synonym. However, Takahashi [22] described "Thoracaphis saramaoensis" based on apterae collected from the deciduous Quercus variabilis at "Kunugigaoka near Saramao (altitude about $2061 \mathrm{~m})$," Taiwan, and he [8] applied this name to the Japanese material "with some hesitation." In Japan, Quercus variabilis is a rather common tree, but no Neothoracaphis species have been recorded from it up to now. In addition, there have been known no other species of Nipponaphidini that utilize $Q$. variabilis and evergreen oaks such as Q. glauca as host plants. It is therefore likely that Takahashi's [8] "T. saramaoensis" is a different species from the focal species of the present paper. For this reason, we adopt the name Neothoracaphis glaucae (Takahashi, 1958) for the focal species.

Miyazaki et al. [23] also regarded N. querciphaga and $N$. elongata as a single species. This turned out to be a mistake. Takahashi [8] illustrated a rather large individual of the apterous adult of $N$. querciphaga. Although our morphometric analyses showed that there is considerable variation in size among individual apterae of $N$. querciphaga (Figures 2(c), 2(d), and 8), the mitochondrial sequence data (Figure 6) clearly indicated that $N$. elongata is a distinct species.

Our molecular analyses also indicate that, among the Japanese Nipponaphidini species, N. glaucae, N. querciphaga, and N. elongata form a monophyletic group and that the genus Neothoracaphis (the above three species plus N. yanonis) is also monophyletic. Takahashi [8] originally placed the first three species in the genus Microthoracaphis and yanonis in Neothoracaphis, but Eastop and Hille Ris Lambers [24] later united the two into one genus and adopted Neothoracaphis as the valid genus name. The results of our analyses do not contradict either treatment. We follow Eastop and Hille Ris Lambers [24], as do Blackman and Eastop [2] and Favret [3].

4.2. Production of Alates in Neothoracaphis glaucae. Colonies of Neothoracaphis yanonis on leaves of deciduous oaks (Quercus serrata, Q. dentata, and Q. crispula) produce many alate sexuparae in autumn $[2,5,8]$. Neothoracaphis quercicola is also known to produce alates on deciduous oaks (Q. acutissima and Q. variabilis) in Taiwan and China 


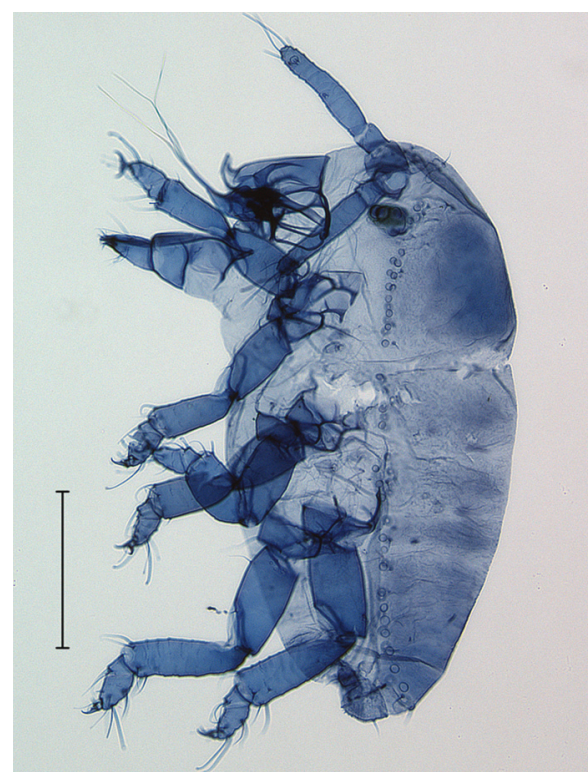

(a)

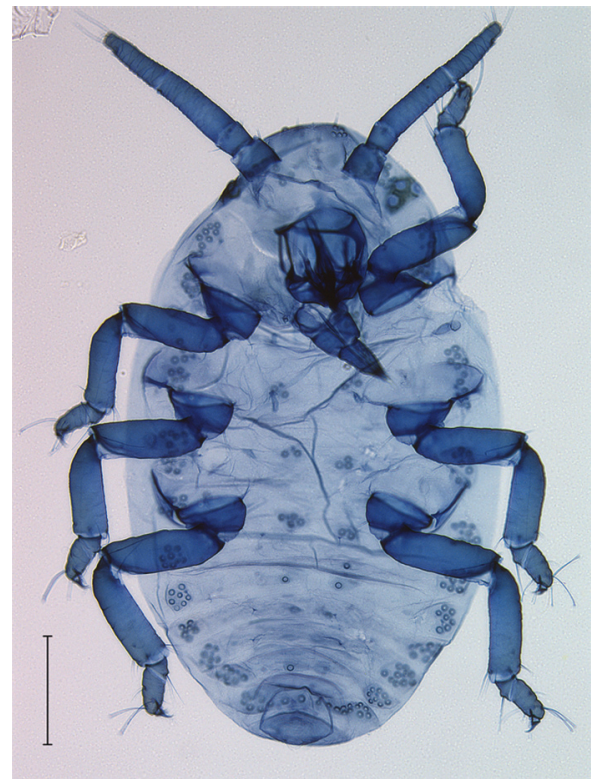

(c)

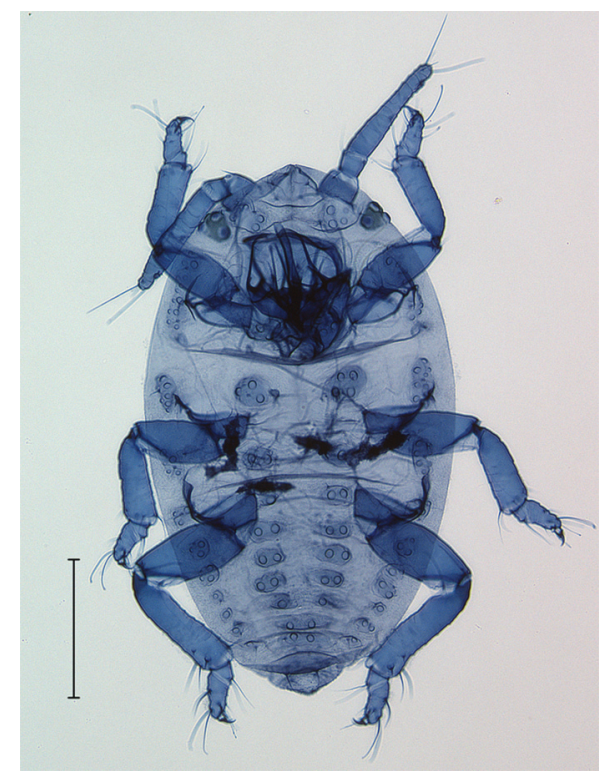

(b)

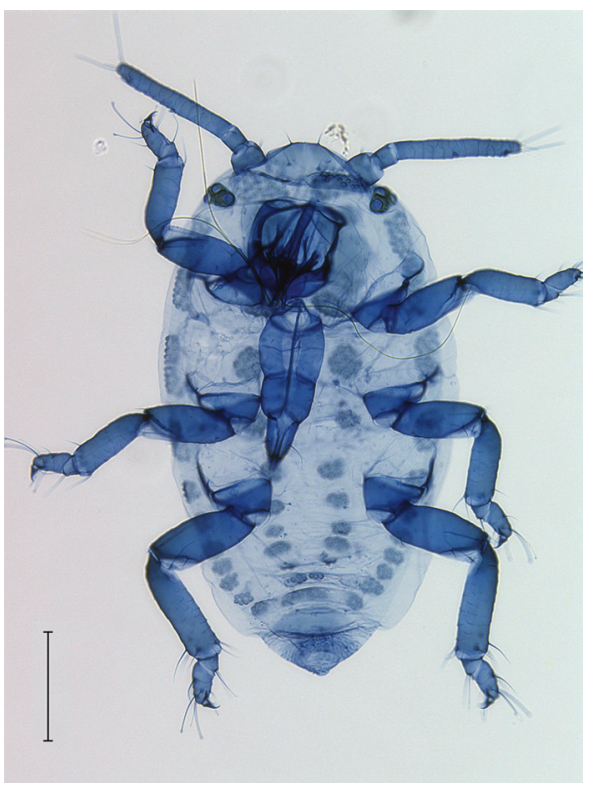

(d)

Figure 9: Nymphs of Neothoracaphis yanonis: (a) first-instar nymph to be aptera (collected from Quercus serrata on 8 October 2014); (b) first-instar nymph to be alate sexupara (collected from Q. serrata on 8 October 2014); (c) first-instar male produced by the alate sexupara (collected from Q. serrata on 13 November 2013 and fixed on 18 November 2013); (d) first-instar female (collected from Distylium racemosum on 23 November 2013). All aphids were collected in Tama, Tokyo, Japan. Scale bars: $100 \mu \mathrm{m}$.

$[1,2,25]$. However, alates have hitherto been unknown from Neothoracaphis species on evergreen oaks [2, 8]. In this study, we found that N. glaucae produces alates from November to January in Tokyo, Japan. As has been reported in some Nipponaphidini species such as Reticulaphis sp. [26], Thoracaphis kashifolia [27], and Dermaphis coccidiformis [21], nymphs that develop into alates are different from those that develop into apterae in morphology from the first instar. Such clear morphological differentiation in the first instar between the alate and apterous generations on the secondary host seems to occur in a number of nipponaphidine species with small apterae but not in species with rather large apterae like Nipponaphis spp. [20, 28].

In $N$. glaucae, nymphs to be alates were covered with bristle-like semitransparent wax filaments (Figure 1(c)) and larger in the fourth instar than apterous adults. Well-developed wax plates were seen on the tergites of the slidemounted specimens (Figures 4(c) and 5(d)). In N. yanonis, nymphs that develop into alates (Figures 9(b) and 5(e)) are also different from those that develop into apterae (Figure 9(a)), but they do not produce long bristle-like wax filaments but shorter, needle-shaped wax filaments (see a 
TABLE 4: Main morphological differences between sexes in the first instar of Neothoracaphis yanonis.

\begin{tabular}{ll}
\hline Female & Male \\
\hline $\begin{array}{l}\text { Body: smaller than male, } 0.42-0.49 \text { (mean } 0.46) \mathrm{mm} \\
\text { in length }(n=10) \text {; hind femorotrochanter: } 89-105\end{array}$ & $\begin{array}{l}\text { Body: 0.56-0.60 }(0.58) \text { mm in length }(n=9) \text {; hind } \\
\text { femorotrochanter: } 104-113(109) \mu \mathrm{m} \text { long }(n=9)\end{array}$ \\
$\begin{array}{l}\text { Antenna: } 3 \text {-segmented; apical segment: } 98-123(114) \\
\mu \mathrm{m} \text { long }(n=10)\end{array}$ & $\begin{array}{l}\text { Antenna: 4-segmented; apical two segments } \\
\text { combined: } 130-145(137) \mu \mathrm{m} \text { long }(n=9) \text { and } 20-33\end{array}$ \\
$\begin{array}{l}\text { Stylets: far longer than rostrum, approximately } \\
0.21-0.23(0.22) \text { mm long }(n=10)\end{array}$ & $\begin{array}{l}\text { Stylets: short, approximately } 0.06-0.10(0.08) \text { mm } \\
\text { long }(n=9)\end{array}$ \\
$\begin{array}{l}\text { Spinal rows of wax plates: well developed, with 3-8 } \\
(5.4) \text { cells on abdominal tergite VI }(n=10)\end{array}$ & $\begin{array}{l}\text { Spinal rows of wax plates: often reduced, with 0-5 } \\
(1.7) \text { cells on abdominal tergite VI }(n=9)\end{array}$ \\
\hline
\end{tabular}

TABLe 5: Approximate length of the stylets of Neothoracaphis glaucae and N. yanonis.

\begin{tabular}{lc}
\hline & Stylet length in $\mathrm{mm}$ \\
\hline $\begin{array}{l}\text { N. glaucae: morph } \\
\text { First-instar nymph to be aptera }\end{array}$ & 0.15 (mean 0.15$)(n=10)$ \\
First-instar nymph to be alate & $0.14(n=1)$ \\
Fourth-instar wingpadded nymph & $0.14-0.18(0.16)(n=10)$ \\
First-instar nymph produced by the & $0.25-0.29(0.27)(n=40)$ \\
alate & \\
N. yanonis: morph & $0.10-0.12($ mean 0.11$)(n=$ \\
First-instar nymph to be aptera & $10)$ \\
First-instar nymph to be alate & $0.11-0.13(0.12)(n=10)$ \\
Fourth-instar wingpadded nymph & $0.11-0.12(0.11)(n=5)$ \\
First-instar female & $0.21-0.23(0.22)(n=10)$ \\
First-instar male & $0.06-0.10(0.08)(n=9)$ \\
\hline
\end{tabular}

photo in [5]). It is unknown why the nymphs developing into alates of $N$. glaucae have such long wax filaments. The long bristle-like filaments, just like bristles, might help the nymphs to perceive predators approaching them.

In the tribe Nipponaphidini, alates produced on the secondary host are either sexuparae that fly to the primary host or "secondary migrants" that fly to trees of the secondary host. Neothoracaphis yanonis produces sexuparae [8], while Thoracaphis kashifolia is known to produce secondary migrants only [27]. The alates (secondary migrants) of T. kashifolia give birth to first-instar nymphs that are morphologically the same as those produced by the apterae [27]. The sexuparae of $N$. yanonis produce dimorphic firstinstar nymphs that develop into males and sexual females. The first-instar females (Figure 9(d)) are smaller than the first-instar males (Figure 9(c)), but the stylets of the former are much longer than those of the latter (Table 4). Both of these first-instar sexuals are distinct from the first-instar nymphs that develop into apterae (Figure 9(a)) in having rows of spinal wax plates on the tergites. In this respect, they are similar to the first-instar nymphs that develop into alate sexuparae (Figure 9(b)). The stylets of the first-instar females are longer than the stylets of first-instar nymphs to be apterae and nymphs to be alate sexuparae, which are longer than the stylets of first-instar males (Table 5).

The alates of $N$. glaucae are rather enigmatic. The 44 firstinstar nymphs produced by alates had well-developed spinal rows of wax plates on their tergites (Figure 4(d)). In morphology, they are quite different from first-instar nymphs that develop into apterae (Figure 4(a)). They are rather similar to first-instar nymphs that develop into alates (Figure 4(c)), but their stylets are clearly longer than those of the latter (Table 5). It is therefore unlikely that they are nymphs that grow on leaves of Q. glauca. In comparison with $N$. yanonis, they are likely to be first-instar sexual females. However, among the 44 nymphs produced by alates, we found no first-instar nymphs which had shorter stylets and seemed to be first-instar males. To confirm this, we also examined the morphology of a total of 259 embryos remaining in the bodies of 58 slide-mounted alates. Except for 23 embryos which were heavily distorted and could not be identified, the remaining 236 were not different from the 44 nymphs in morphology. We here present two hypotheses to explain the situation: (1) The first-instar nymphs were of the sexual female, and no males were contained in the sample. Sexuparae of N. glaucae that produce males might occur elsewhere, in other clones. (2) The first-instar nymphs actually consisted of both sexes, and sexual dimorphism might have merely been indiscernible in the first instar of N. glaucae.

4.3. Dimorphic Apterous Adults. Although we showed that $N$. glaucae produces dimorphic apterous adults on leaves of the host oak Quercus glauca, it remains still unclear why such dimorphic apterae occur in this species. Both S-type and L-type apterous adults produce first-instar nymphs that develop into apterae. In the tribe Nipponaphidini, because of their strongly sclerotized tergites, it is difficult to examine the morphology of embryos in the bodies of slide-mounted apterous adults. However, we found four S-type adults and an L-type adult (collected in Shinkiba on 25 November 2013) which each were just giving birth to a first-instar nymph. Also, we observed four L-type adults (collected in Shinkiba) producing nymphs in the laboratory on 1 and 2 April 2013. All these newly born nymphs were those to be apterae. We did not determine which types of apterae produce nymphs that develop into alates, but the production of alates is likely to be irrelevant to the dimorphism. (In N. yanonis, monomorphic tiny apterae produce nymphs that develop into apterae and alates.) Some S-type apterae contained a single mature embryo which occupied the majority of the body cavity, while some L-type apterae contained more than 
one developed embryo. This suggests that, under favorable conditions, L-type apterae are more productive than S-type apterae. L-type apterae were more abundant in January, March, and June than in September and November (Table 3). In addition, apterae collected from new leaves of $Q$. glauca from May to September were all of S-type, indicating that first-instar nymphs that have settled on new leaves become S-type apterous adults. We found fresh, undoubtedly live L-type apterae in Shinkiba from the end of November onward. Winter and spring, and not summer or early autumn, may be their favorable seasons for reproduction in and around Tokyo.

\section{Conclusion}

In this paper, we made it clear that the aphid Neothoracaphis glaucae produces dimorphic sessile apterous adults on leaves of the evergreen Quercus glauca. Apterae of the smaller type (S-type) are abundantly seen throughout the year, while those of the larger type (L-type) are few in number from summer to early autumn. We provisionally conclude that the latter may be produced in the favorable seasons for reproduction. Such clear dimorphism in size and shape has hitherto been unknown among aphids with sessile apterae. It will be interesting to know whether there are other species with similar dimorphism and, if not, why only $N$. glaucae maintains the dimorphism.

\section{Data Availability}

The DNA sequence data used to support the findings of this study have been deposited in the DDBJ/EMBL/GenBank nucleotide sequence database repository (http://www.insdc. org/).

\section{Conflicts of Interest}

The authors declare that they have no conflicts of interest.

\section{Acknowledgments}

The authors thank Shunichiro Sugimoto, Kazuo Koyanagi, Naeko Hosoya, Akihide Koguchi, and Morio Tsukada for their help in collecting materials used in this study.

\section{Supplementary Materials}

Figure S1: scatter diagram of body length versus body width for apterous adults of Neothoracaphis glaucae (sample \#14008), with a frequency distribution diagram of the body lengths $(40 \mu \mathrm{m}$ for 1 unit of the axis). Figure S2: scatter diagram of body length versus body width for apterous adults of Neothoracaphis glaucae (sample \#14117), with a frequency distribution diagram of the body lengths $(40 \mu \mathrm{m}$ for 1 unit of the axis). Figure S3: scatter diagram of body length versus body width for apterous adults of $\mathrm{NeO}$ thoracaphis glaucae (sample \#13117), with a frequency distribution diagram of the body lengths ( $40 \mu \mathrm{m}$ for 1 unit of the axis). Figure S4: scatter diagram of body length versus body width for apterous adults of Neothoracaphis glaucae (sample \#14172), with a frequency distribution diagram of the body lengths ( $40 \mu \mathrm{m}$ for 1 unit of the axis). Figure S5: scatter diagram of body length versus body width for apterous adults of Neothoracaphis glaucae (sample \#14115), with a frequency distribution diagram of the body lengths ( $40 \mu \mathrm{m}$ for 1 unit of the axis). Figure S6: adult male of Neothoracaphis yanonis (collected from Distylium racemosum in Tama, Tokyo, Japan, on 8 January 2014). Scale bar: $100 \mu \mathrm{m}$. (Supplementary Materials)

\section{References}

[1] J. Chen, L. Jiang, and G. Qiao, "Revision of Neothoracaphis Takahashi with description of a new species from China (Hemiptera: Aphididae: Hormaphidinae)," Oriental Insects, vol. 45, no. 2-3, pp. 146-161, 2011.

[2] R. L. Blackman and V. F. Eastop, Aphids on the World's Plants, John Wiley and Sons, Hoboken, NJ, USA, 2019, http://www. aphidsonworldsplants.info/.

[3] C. Favret, Aphid Species File Version 5.0/5.0 2019, http:// Aphid.SpeciesFile.org.

[4] R. Takahashi, "Aphididae of Formosa part 2," Report of Department of Agriculture, Government Research Institute Formosa, no. 4, pp. 1-173, 1923.

[5] M. Moritsu, Aphids of Japan in Colors, Zenkoku Noson Kyoiku Kyokai, Tokyo, Japan, in Japanese, 1983.

[6] J. Yukawa and H. Masuda, Insect and Mite Galls of Japan in Colors, Zenkoku Noson Kyoiku Kyokai, Tokyo, Japan, 1996, in Japanese.

[7] P. O. Ngakan and J. Yukawa, "Gall site preference and intraspecific competition of Neothoracaphis yanonis (Homoptera: Aphididae)," Applied Entomology and Zoology, vol. 31, no. 2, pp. 299-310, 1996.

[8] R. Takahashi, "Two new genera of Aphididae from Quercus in Japan (Homoptera)," Bulletin of University of Osaka Prefecture, Series B, vol. 8, pp. 1-7, 1958.

[9] M. Sorin, "Aphids of the planted trees part 3," Shokubutsu Boeki [Plant Protection], vol. 57, no. 9, pp. 41-44, 2003, in Japanese.

[10] J. Yukawa and K. Tsuda, "Leaf longevity of Quercus glauca Thunb., with reference to the influence of gall formation by Contarinia sp. (Diptera: Cecidomyiidae) on the early mortality of fresh leaves," Memoirs of the Faculty of Agriculture, Kagoshima University, vol. 22, pp. 73-77, 1986.

[11] K. Kikuzawa, Ecology of Leaf Longevity, Kyoritu-huppan, Tokyo, Japan, 2005, in Japanese.

[12] J. A. Hartigan and P. M. Hartigan, "The dip test of unimodality," The Annals of Statistics, vol. 13, no. 1, pp. 70-84, 1985.

[13] R Core Team, R: A Language and Environment for Statistical Computing, R Foundation for Statistical Computing, Vienna, Austria, 2015.

[14] U. Kurosu, M. Kutsukake, S. Aoki, C.-C. Wang, H.-J. Lee, and T. Fukatsu, "Galls of Cerataphis bambusifoliae (Hemiptera, Aphididae) found on Styrax suberifolius in Taiwan," Zoological Studies, vol. 47, no. 2, pp. 191-199, 2008.

[15] R. C. Edgar, "MUSCLE: multiple sequence alignment with high accuracy and high throughput," Nucleic Acids Research, vol. 32, no. 5, pp. 1792-1797, 2004.

[16] S. Kumar, G. Stecher, and K. Tamura, "MEGA7: molecular evolutionary genetics analysis version 7.0 for bigger datasets," Molecular Biology and Evolution, vol. 33, no. 7, pp. 1870-1874, 2016. 
[17] K. Tamura and M. Nei, "Estimation of the number of nucleotide substitutions in the control region of mitochondrial DNA in humans and chimpanzees," Molecular Biology and Evolution, vol. 10, no. 3, pp. 512-526, 1993.

[18] T. Fukatsu, H. Shibao, N. Nikoh, and S. Aoki, "Genetically distinct populations in an Asian soldier-producing aphid, Pseudoregma bambucicola (Homoptera: Aphididae), identified by DNA fingerprinting and molecular phylogenetic analysis," Molecular Phylogenetics and Evolution, vol. 18, no. 3, pp. 423-433, 2001.

[19] M. Kutsukake, X. Y. Meng, N. Katayama, N. Nikoh, H. Shibao, and T. Fukatsu, "An insect-induced novel plant phenotype for sustaining social life in a closed system," Nature Communications, vol. 3, Article ID 1187, 2012.

[20] S. Aoki, M. Kutsukake, U. Kurosu, H.-T. Yeh, M. Sano, and T. Fukatsu, "Nipponaphis species (Aphididae: Hormaphidinae) that form green galls on Distylium racemosum in Japan," Entomological Science, vol. 18, no. 4, pp. 420-434, 2015.

[21] S. Aoki, U. Kurosu, K. Uematsu, T. Fukatsu, and M. Kutsukake, "Dermaphis coccidiformis sp. nov. (Hemiptera), an aphid species with asymmetrically sclerotized apterae and "winter alates"," Entomological Science, vol. 21, no. 2, pp. 142-153, 2018.

[22] R. Takahashi, "Three new aphids of the genus Thoracaphis, van der Goot (Hem.)," Stylops, vol. 4, no. 4, pp. 86-89, 1935.

[23] M. Miyazaki, S. Aoki, and M. Sano, "Family Aphididae," in Catalogue of the Insects of Japan, T. Saigusa, K. Araya, S. Eda et al., Eds., vol. 4, Touka Shobo, Fukuoka, Japan, pp. 96-173, 2016, in Japanese.

[24] V. F. Eastop and D. Hille Ris Lambers, Survey of the World's Aphids, Dr. W. Junk, The Hague, the Netherlands, 1976.

[25] R. Takahashi, "Aphididae of Formosa part 6," Report of Department of Agriculture, Government Research Institute, Formosa, no. 53, pp. 1-127, 1931.

[26] E. C. Zimmerman, Insects of Hawaii Volume 5 Homoptera: Sternorhyncha, University of Hawaii Press, Honolulu, HI, USA, 1948.

[27] U. Kurosu, S. Aoki, K. Uematsu, M. Kutsukake, and T. Fukatsu, "Defensive nymphs of the woolly aphid Thoracaphis kashifolia (Hemiptera) on the oak Quercus glauca," Psyche, vol. 2016, Article ID 4036571, 11 pages, 2016.

[28] S. Aoki, U. Kurosu, K. Uematsu, T. Fukatsu, and M. Kutsukake, "Two closely related species of Nipponaphis (Hemiptera: Aphididae) that migrate between Distylium racemosum and Machilus trees in Japan," Entomological Science, vol. 22, no. 2, pp. 220-229, 2019. 


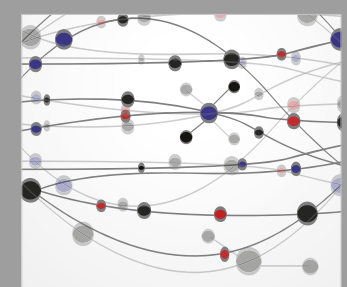

The Scientific World Journal
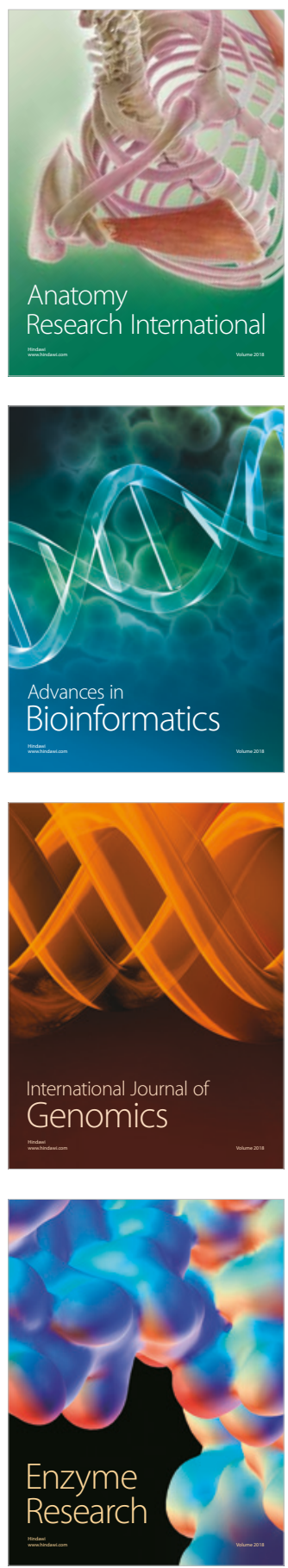
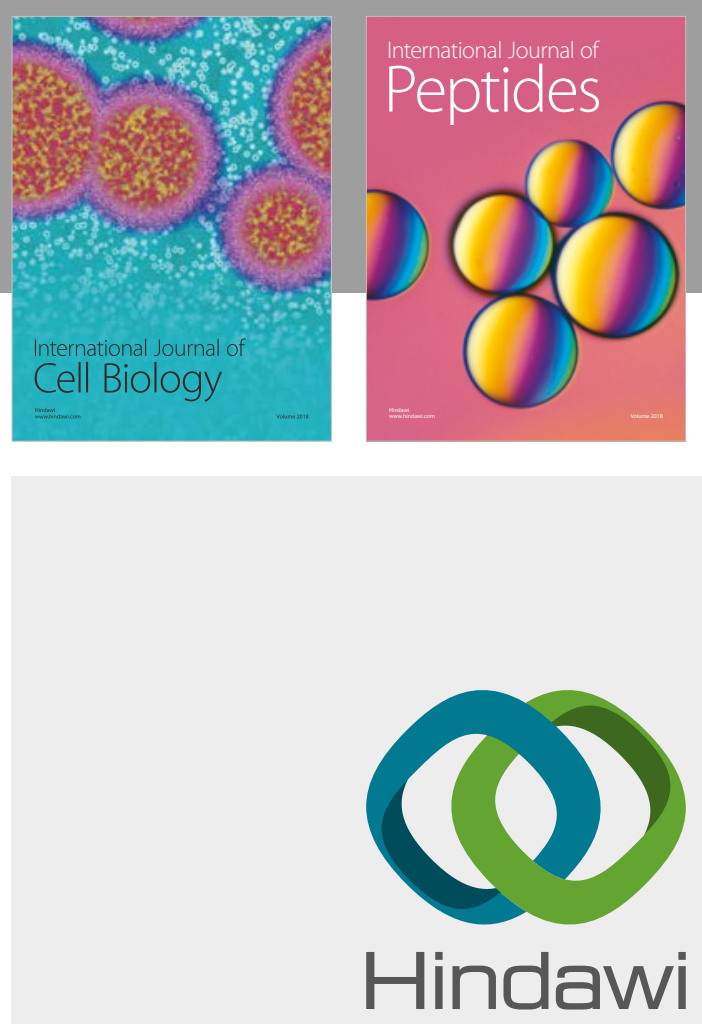

Submit your manuscripts at

www.hindawi.com
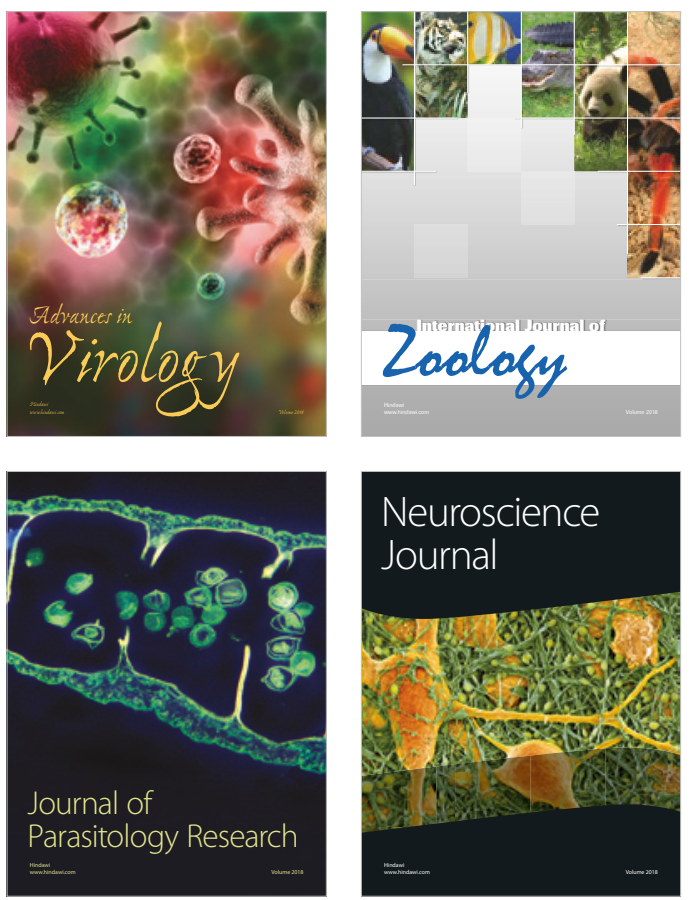
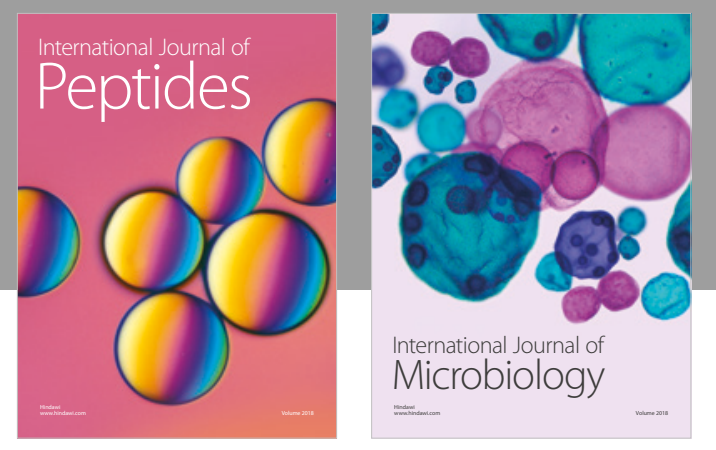

nternational Journal of Microbiology
Journal of
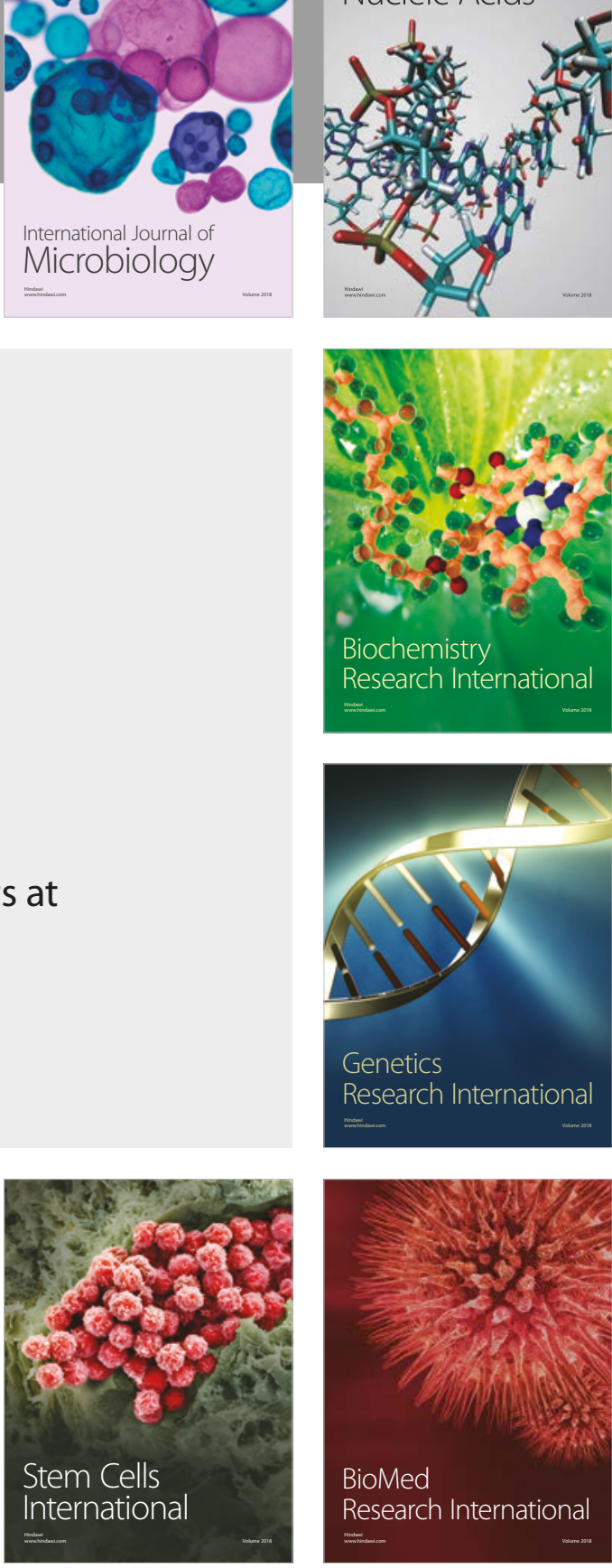
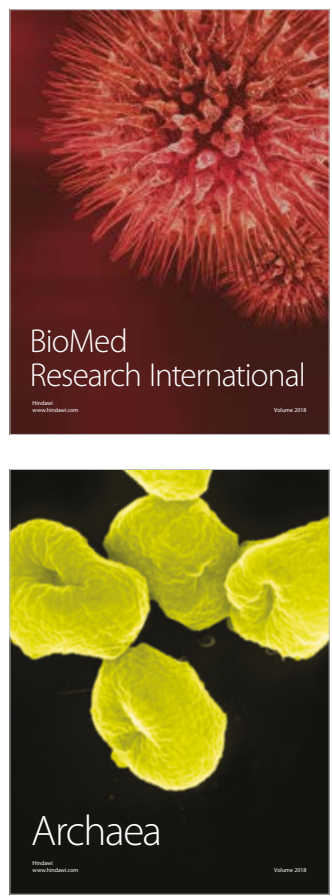